\title{
Ediacaran/Early Cambrian Serra da Saudade Formation, Bambuí Group: the sedimentary record of a foreland basin in Southeastern Brazil
}

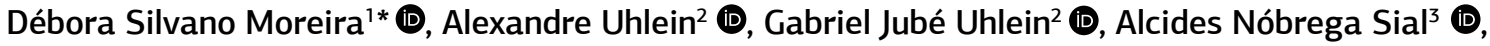 \\ Edinei Koester ${ }^{4}$ (D)
}

\begin{abstract}
The Serra da Saudade Formation, Ediacaran/Cambrian Bambuí Group, cropping out along the ridge of the same name in Central-Western Minas Gerais, Brazil, contains important deposits of glauconitic siltstones associated with phosphatic rhythmite as well as other siliciclastic, volcaniclastic and carbonate lithofacies. Lithofacies indicate deposition by proximal and distal storm waves on a continental marine shelf. The basal gray siltstone and part of the green siltstone represent a transgressive systems tract. The glauconitic siltstone indicates sea level rise, with the maximum flooding surface located approximately at the interval of highest $\mathrm{K}_{2} \mathrm{O}$ content. Biogenic carbonate and an upward increase in sandstone beds are interpreted as a highstand systems tract. Gradual lateral facies changes reflect the transition from foredeep (to the west) to forebulge (to the east) deposition in a foreland basin as the final stage of a shallowing-upward second-order sequence. Black organic-rich limestone has $\delta^{13} \mathrm{C}$ values between -8.78 and $9.79 \%$, negative $\delta^{18} \mathrm{O}$ values from -11.50 to $-9.35 \%$, and ${ }^{87} \mathrm{Sr} /{ }^{86} \mathrm{Sr}$ around 0.7075 . This isotopic signature, similar to that of other Bambuí carbonates, indicates a probably-restricted depositional environment with organic sedimentation, methanogenesis and high evaporation rates from the Ediacaran through the early Cambrian period.
\end{abstract}

KEYWORDS: Glauconitic siltstone; phosphorite, foredeep/forebulge transition; C-O-Sr isotopic geochemistry

\section{INTRODUCTION}

The Serra da Saudade ridge, in the Alto Paranaíba region (Minas Gerais, Brazil), represents the largest exposed portion of the Serra da Saudade Formation, Bambuí Group. This geological unit is well known from numerous studies since the 1960 s, which have documented the occurrence of phosphate-rich rhythmite and glauconitic siltstone, with the potential to be used as fertilizer inputs (Costa and Branco 1961, Guimarães 1967, Chaves et al. 1971, Dardenne 1978, Lima et al. 2007, Moreira et al.2016, Nader and Ackroyd 2017). However, despite the large number of studies related to the Serra da Saudade Formation, few publications have correlated the lithofacies in different regions of the type-section (São Gotardo and Cedro do Abaeté) and studied the stratigraphy and depositional environment of the Serra da Saudade Formation in detail.

\footnotetext{
${ }^{1}$ Programa de Pós-Graduação em Geologia, Instituto de Geociências, Universidade Federal de Minas Gerais - Belo Horizonte (MG), Brazil. E-mail: moreiradebora@yahoo.com

${ }^{2}$ Centro de Pesquisas Manoel Teixeira da Costa, Instituto de Geociências, Universidade Federal de Minas Gerais - Belo Horizonte (MG), Brazil. E-mails: auhlein@gmail.com,guhlein@gmail.com

${ }^{3}$ Núcleo de Estudos Geoquímicos, Laboratório de Isótopos Estáveis, Universidade Federal de Pernambuco - Recife (PE), Brazil. E-mail: sial@ufpe.br

${ }^{4}$ Instituto de Geociências, Universidade Federal do Rio Grande do Sul Porto Alegre (RS), Brazil. E-mail: edineikoester@yahoo.com.br

${ }^{*}$ Corresponding author.
}

The Serra da Saudade Formation is interpreted as part of the record of a foreland basin that formed proximal to the Brasília Belt (Dardenne 2000, Alkmim and Martins-Neto 2001, 2012, Alkmim et al. 2011, Reis et al.2017, Uhlein et al. 2017). A foreland system consists of four depozones, referred to as the wedgetop, foredeep, forebulge and back-bulge. The foredeep depozone accumulates gravity flow and pelagic sediments during its early, underfilled stage. The forebulge is characterized by a flexural uplift between the foredeep and the back-bulge deposits. Finally, the back-bulge is the mass of sediments in the shallow craton-ward region. Changes in complexes of variables as flexural subsidence due to topographic and sediment loads may affect depozones in different ways, reflecting in the sediment composition and basin architecture. The orogenic growth is correlated to fine-grained sedimentation through most of the foreland basin, while periods of tectonic quiescence reflect in coarse-grained influxes, explaining the lateral and vertical variation in lithofacies along the basin (DeCelles and Giles 1996). A deeper quiet environment may have led to sediment starvation with authigenic glauconite and phosphate development (Reading 1996). Glauconitic-phosphatic beds, interbedded with resedimented limestone, can be attributed to sedimentation processes associated with intervals of maximum flooding in tectonically active situations and a depositional hiatus on submarine highs that separate carbonate transgressive systems tract (TST) from a terrigenous tempestite highstand systems tract (Riggs and Sheldon 1990, Özgüner and Varol 2009).

According to various papers that summarize the importance of the authigenic glauconite (e.g. Dooley 2006, Udgata 2007), 
the first acknowledgment of this new mineral happened in the XVII century. It is found in sedimentary deposits, distributed from the Precambrian to as recent as blueish-green pellets, granular and micaceous grains. The glauconite belongs to a mineral series ranging from smectite to glauconite, according to its maturity, related to its $\mathrm{K}_{2} \mathrm{O}$ content. It is typically formed during times of intense flooding in a transitional environment, between talud and platform at 50 to $500 \mathrm{~m}$ deep, normal salinity and basic $\mathrm{pH}$, favored by reducing environments with presence of organic matter (Amorosi, 1995, 1997, Dooley 2006, Amorosi et al. 2007). Since concentration and maturity of glauconite are controlled by sea level fluctuations, the autochthonous and highly evolved glauconite is characterized by a mature evolutionary stage in TST, whereas dark green grains have $\mathrm{K}_{2} \mathrm{O}$ content up to $8 \mathrm{wt} \%$ is common (Amorosi 1995).

Phosphatic crusts may be attributed to the activity of bottom currents (upwelling) that may influence the depositional surface of the outer continental shelf or a carbonate platform (Föllmi 1996, Özgüner and Varol 2009). Phosphor is one of the main macronutrients, and global phosphogenic events coincide with major evolutionary innovation during the Ediacaran and Cambrian periods, followed by episodes of atmospheric oxygenation (Cook and Shergold 1984, Algabri et al. 2020).

Glauconite and sedimentary phosphorite associations are common around the world, indicating specific conditions in a marine sedimentary environment. In the Ediacaran Doushantuo Formation (Weng'an, South China), the apatite-glauconite association may be related with intervals of warm climates, hypoxic shelf, low rate of sedimentation, as well as an enhanced rate of continental weathering, responsible for excessive supply of nutrients and high organic productivity, and it is considered a useful mineralogical proxy for paleoredox conditions on the Precambrian ocean floor (Algabri et al. 2020, Banerjee et al.2020). The Upper Ediacaran to lower Cambrian foreland basin deposits formed in the Zavkhan Terrane (Southwestern Mongolia) identified glauconite in the form of nodules and cement associated with the Archaeocyatha within phosphatized lenses (Pruss et al. 2019). On the upper Paleozoic foreland of the Uralian fold belt, a fully transgressive-progradation section exhibits an association of volcaniclastic glauconite and phosphorites (Proust et al. 1998). In West Africa, phosphorites are associated with the young, short-lived tectonic cycle that occurred during the aggregation of Western Gondwana in late Neoproterozoic time. These phosphorites are related to or immediately follow the eustatic transgression on a foreland basin, possibly occurring during the early Cambrian age, and are also associated with glauconitization processes (Flicoteaux and Trompette 1998).

This paper focuses on the stratigraphic analysis of the Serra da Saudade Formation and describes the glauconitic siltstone and phosphorite deposits. It aims to describe and interpret the lithofacies, as well as analyzing its depositional environments and sedimentary process. The Serra da Saudade Formation is discussed in terms of its sequence-stratigraphic framework, as well as its significance to the regional paleogeography of the Bambuí basin. This study also presents new lithogeochemistry and C-O-Sr isotopic data for the carbonate rocks. The results allow to consolidate the knowledge about the Serra da Saudade Formation and understand the characteristics of their sedimentary deposition in the Bambuí Basin context. To this effect, a thorough review has been presented, combining new data with previous works done in the study area.

\section{GEOLOGICAL BACKGROUND}

The Serra da Saudade Formation is part of the Ediacaran/ early Cambrian Bambuí Group, a sedimentary cover of the Western São Francisco craton (Dardenne 1978, 2000, Sial et al. 2009, Moreira et al. 2020). The São Francisco Craton was one of the paleocontinents involved in the assembly of the Gondwana in late Neoproterozoic and Cambrian, surrounded by the Brasiliano/Pan-African Araçuaí-West Congo Belt to the east, the Brasília Belt to the west and the Rio Preto Belt to the north (Trompette 1994, Cordani et al. 2000).

The Bambuí Group comprises mixed carbonate-siliciclastic sedimentary units deposited in a foreland basin linked to the Brasília Belt evolution (Dardenne 2000, Pimentel et al. 2001, Alkmim and Martins-Neto 2012, Reis et al. 2017, Uhlein et al. 2017). The lithostratigraphy of the Bambuí Group consists of a basal diamictite-bearing unit (Jequitaí Formation) deposited under glacial influence and overlapped by a thick $(>900 \mathrm{~m})$ marine shale-carbonate succession, comprising the following formations (according to the stratigraphy defined by authors, such as Dardenne 1978, 2000, Castro and Dardenne 2000, Kuchenbecker et al. 2016, Uhlein et al. 2011, 2017, 2019):

- Sete Lagoas Formation: limestone and dolostone;

- Serra de Santa Helena Formation: shale, siltstone and rare limestone;

- Lagoa do Jacaré Formation: limestone and shale;

- Serra da Saudade Formation: siltstone, sandstone, glauconitic siltstone, phosphorite and rare limestone;

- Três Marias Formation: sandstone and siltstone.

Exposed in the western portion of the basin, the Samburá Formation - conglomerate and siltstone (Castro and Dardenne 2000, Uhlein et al. 2017); and the Lagoa Formosa Formation diamictite, sandstone, siltstone with interbedded limestone and jaspilite; have been considered lateral stratigraphic equivalents of the lower Sete Lagoas Formation (i.e., the Pedro Leopoldo Member) and the Serra de Saudade Formation, respectively (Uhlein et al. 2011, Uhlein et al. 2017).

The Serra da Saudade Formation crops out in a continuous Southwest-Northeast (SW) strip, mainly in the homonymous ridge (Fig. 1) and is comprised of pelitic-sandy sedimentary rocks, including pelitic-psammitic rhythmite, sandstone with hummocky cross-stratification, green siltstone, glauconitic siltstone, phosphatic rhythmite, reworked carbonate and minor occurrences of limestone (Costa and Branco 1961, Guimarães 1967, Chaves et al. 1971, Dardenne 1978, Lima et al. 2007, Seer and Moraes 2011b, Moreira et al. 2016).

The geology of the Serra da Saudade ridge, specifically in the Cedro do Abaeté region, was first described by Guimarães (1967) and later by the Projeto Fosfato de Cedro do Abaeté (Chaves et al. 1971). Later, Lima et al. (2007) detailed the 


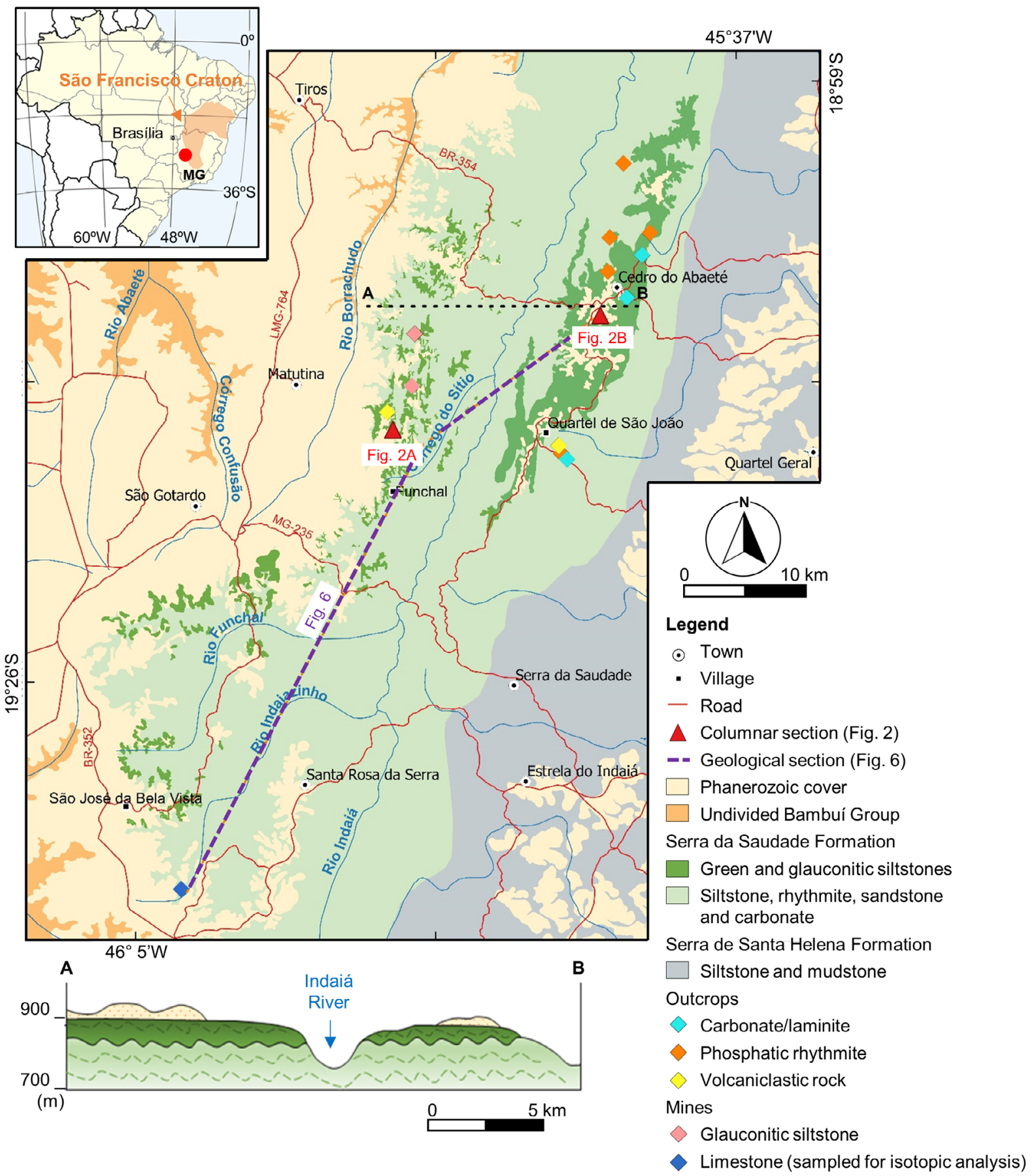

Figure 1. Simplified geological map of the study area, in the context of the São Francisco Craton, presenting the locations of columnar sections (Fig. 2), geological sections (A-B; and Fig. 6) and the quarry sampled for isotopic analysis. Modified from Chaves et al. (1971), Signorelli et al. (2003), Nader and Ackroyd (2017), Moreira et al. (2016).

Serra da Saudade Formation lithotypes and the genesis of the phosphatic mineralization. The São Gotardo region was studied by Moreira et al. (2016), who described the glauconitic siltstone unit with $\mathrm{K}_{2} \mathrm{O}$ concentrations of up to $10 \mathrm{wt} \%$, used to produce potash fertilizers (Violatti et al. 2019).

The Serra da Saudade Formation also outcrops in small areas of the northern sector (Felixlândia, Unaí, Montes Claros and Jaíba towns). In the Jaíba section, located $500 \mathrm{~km}$ northward of the study area, several studies documented carbonate facies and their geochemical signature (Chiavegatto et al. 2003, Iglesias and Uhlein 2009, Costa 2011, Kuchenbecker et al. 2016, Uhlein et al. 2019, 2021, Kelmer 2019).
The Serra da Saudade Formation's depositional environment is interpreted as a foreland basin, which embraces five transgressive-regressive cycles (Reis et al. 2017, Uhlein et al. $2017,2019)$. In general, this unit defines a basal transgression followed by a regression, with sandy inputs and limestone occurrences of up until the deposition of the thick sandstone of the Três Marias Formation (Uhlein et al. 2017, 2019).

The depositional age of the Bambuí Group was intensively debated in the last decades. $\mathrm{A} \mathrm{Pb}-\mathrm{Pb}$ whole-rock isochron array of $740 \pm 22 \mathrm{Ma}$ on the cap carbonate of the Sete Lagoas Formation has indicated a likely post-Sturtian age (Babinski et al.2007), in agreement with the maximum depositional age $(\sim 880 \mathrm{Ma})$ for the Jequitaí diamictite, related to the Sturtian 
glaciation (Vieira et al. 2007, Rodrigues 2008, Babinski et al. 2012). However, due to the presence of pinkish cap dolomite at the base of the Sete Lagoas Formation (Caxito et al. 2012, 2018) with upwards-decreasing carbon isotope profiles, as well as ${ }^{87} \mathrm{Sr} /{ }^{86} \mathrm{Sr}$ signatures of limestones between 0.7074 to 0.7080 (Caxito et al. 2012), a post-Marinoan age ( $635 \mathrm{Ma})$ is more accepted nowadays. The lateral stratigraphic equivalent, Samburá Formation, yielded a maximum depositional age of $\sim 630 \mathrm{Ma}$, based on detrital zircon grains obtained from conglomerate rocks (Uhlein et al. 2017). Crockford et al. (2018) also suggested a post-Marinoan (ca. $630 \mathrm{Ma}$ ) age for the Sete Lagoas Formation's cap carbonate rocks in the Januária region (Northern Minas Gerais) using triple oxygen and sulfur isotopes analyzed on barite layers. The detrital zircon grains from the upper Sete Lagoas Formation are as young as $\sim 560 \mathrm{Ma}$ and yield a maximum sedimentation age of $593 \pm 17 \mathrm{Ma}$ (Paula-Santos et al. 2015). This Ediacaran age is supported by the occurrence of Cloudina sp., a terminal Ediacaran index fossil ( 550-541 Ma), described in the middle Sete Lagoas Formation (Warren et al. 2014). These data, coupled with K-Ar muscovite aged at $567 \pm 17 \mathrm{Ma}$ from garnet-mica-schist and quartzite found in nappes of the external part of the Brasília Orogen (Valeriano et al. 2004), thrusting upon sedimentary rocks of the basal Bambuí Group in the southwestern part of the basin, constrain the depositional age of the lower Sete Lagoas Formation between 630 and $560 \mathrm{Ma}$ (Uhlein et al. 2017). Moreover, a recent $\mathrm{U}-\mathrm{Pb}$ igneous zircon isochron array of 520.2 $\pm 5.3 \mathrm{Ma}$ on a volcaniclastic layer at the upper Serra da Saudade Formation has indicated that the Bambuí Basin deposition reached the late Cryogenian through the early Cambrian (Moreira et al.2020). A Cambrian age for the upper Bambuí Group was also confirmed by recent data from the Três Marias Formation: U-Pb detrital zircon grains as young as $\sim 527 \mathrm{Ma}$ (Tavares et al. 2020) and $\sim 555 \mathrm{Ma}$ (Rossi et al. 2020) and the likely occurrence of the ichnofossil Treptichnus pedum (Sanchez et al. 2021).

\section{MATERIALS AND METHODS}

\section{Geological mapping, field work and sampling}

The geological map used in this study at the 1:500.000 scale (Fig. 1) was based on regional (Signorelli et al. 2003, Seer and Moraes 2011a) and detailed maps, such as the Fosfato Cedro do Abaeté Project at 1:50.000 and 1:5.000 scales (Guimarães and Dutra 1969, Chaves et al. 1971), as well as the Cerrado Verde Potash Project at 1:100.000 scale (Nader and Ackroyd 2017). These maps were adjusted by key geological cross-sections acquired along main and secondary roads connecting the towns of Matutina and Cedro do Abaeté (BR-352), São Gotardo and Serra da Saudade (MG-235).

Detailed measurements were taken along field outcrops. Samples were collected for petrographic, geochemical, and isotopic analysis as further described. Carbonate samples were collected in a quarry located in the Santa Rosa da Serra region (Fig. 1) for geochemical and isotopic analysis of $\mathrm{C}, \mathrm{O}$ and $\mathrm{Sr}$ isotopes, at 3 meter-intervals. Samples were described at the macroscopic and microscopic levels, focusing on lithology recognition and description of primary and secondary features.

\section{Petrography}

Thin-sections were analyzed in detail using a transmitted light binocular microscope (ZEISS AXIOSKOP 40, Laboratório de Caracterização de Rochas Ornamentais, Centro de Pesquisas Manoel Teixeira da Costa, Instituto de Geociências, Universidade Federal de Minas Gerais - CPMTC/IGC/UFMG).

Samples of glauconitic siltstone were analyzed by X-ray diffraction (Centro de Microscopia e Microanálises, Instituto de Desenvolvimento e Pesquisa, Pontifícia Universidade Católica do Rio Grande do Sul - IDEIA-PUC-RS). The clay fraction was oriented and analyzed by the powder method on a Bruker D8 Advance diffractometer, with a copper tube at $40 \mathrm{kV}, 30 \mathrm{~mA}$, 2 Theta from $3^{\circ}$ to $70^{\circ}$, pass of $0,015^{\circ}$ and count time of $0.2 \mathrm{~s}$. The interpretation of diffractograms was performed using the DIFFRAC.EVA V3.1 software and Powder Diffraction File (International Center for Diffraction Data, 2013). A Philips XL 30 scanning electron microscope with coupled energy-dispersive X-ray spectroscopy was also used, where secondary electrons were accelerated at $20 \mathrm{KV}$.

\section{Lithogeochemistry}

After fresh carbonate samples were crushed and powdered, pieces were chosen after macroscopic examination to ensure they were devoid of veins, fractures, mineral fillings, and other features that could potentially affect their geochemical record by late post-depositional processes.

The main oxides were determined by melting the samples with lithium tetraborate and subsequent $\mathrm{X}$-ray fluorescence analysis (AxiosmAX-Minerals ${ }^{\circledR}$, PANalytical, SGS Geosol Laboratórios Ltda). Minor and rare earth elements plus yttrium (REEY) measurements were carried out by inductively coupled plasma mass spectrometry (ICP-MS, SGS Geosol Laboratórios Ltda). The obtained REEY mass fractions were normalized to the Post Archean Australian Shale (PAAS) values (McLennan 1989). Anomalies were calculated as REEYn/REEYn*, where REEYn* was the expected normalized value when extrapolated or interpolated with proper neighbors (Lawrence et al. 2006).

\section{Isotopic analysis}

For the isotopic analysis, in each selected carbonate sample collected in a quarry (Fig. 1), the most homogeneous areas without veins, veinlets, mineral recrystallization or stylolite were selected. In these areas, the material for $\mathrm{C}, \mathrm{O}$ and $\mathrm{Sr}$ isotopic analyses were collected through the micro-drilling technique.

In the $\mathrm{C}$ and $\mathrm{O}$ isotope analysis, $20 \mathrm{mg}$ of each sample were subjected to $\mathrm{CO}_{2}$ gas extraction in a conventional high-vacuum extraction line after reacting with $100 \%$ orthophosphoric acid at $25^{\circ} \mathrm{C}$ for a day. The liberated $\mathrm{CO}_{2}$ gas was cryogenically purified, then analyzed in a double-mass spectrometer and a SIRA II triple collector using the Borborema Skarn Calcite (BSC) reference gas to determine the isotopic 
rations (VG Micromass or Delta V, Thermofinnigan Advantage, Núcleo de Estudos Geoquímicos, Laboratório de Isótopos Estáveis, Departamento de Geologia, Universidade Federal de Pernambuco - NEG-LABISE). The results are expressed in per mille, according to the Vienna PeeDee Beleminite (VPDB) standard. The uncertainties make up less than $0.1 \%$ for carbon and $0.2 \%$ for oxygen, based on multiple analyses of an internal standard.

The Sr purification process was done through the ion exchange chromatography technique. ${ }^{87} \mathrm{Sr} /{ }^{86} \mathrm{Sr}$ ratios were obtained using a multi-collector thermal ionization mass spectrometer (TIMS, Finnigan MAT 262, Laboratório de Geologia Isotópica, Instituto de Geociências, Universidade Federal do Rio Grande do Sul - IGC-UFRGS). The ${ }^{87} \mathrm{Sr} /{ }^{86} \mathrm{Sr}$ ratios were normalized to 0.1194 . The average amount of ${ }^{87} \mathrm{Sr} /{ }^{86} \mathrm{Sr}$ ratios of the NBS-987 standard determined during this study was $0.710260 \pm 0.000040$.

\section{Facies description and interpretation}

The facies were organized according to their granulometry, sedimentary structures and petrographic characteristics in order to construct the columnar sections. The sedimentary facies were defined as a rock unit with distinctive lithologic features (granulometry, sedimentary structures and mineralogical content), reflecting a specific sedimentary process (Reading 1996, James and Dalrymple 2010). In the specific case of the green colored lithofacies, the glauconite content and the $\mathrm{K}_{2} \mathrm{O}$ grade were also considered to distinguish the units. These columnar sections combine data collected from drill cores and field geological profiles performed along the main roads (approximately W-E). Thickness was measured along drill cores or inferred from outcrops.

\section{RESULTS AND DISCUSSION}

\section{Facies and sedimentary process on the Serra da Saudade Formation in its type-section}

The Serra da Saudade Formation is overlain by Cretaceous rocks of the Areado and Mata da Corda groups and by Cenozoic detritic-lateritic covers. The psamo-pelitic rocks of the Serra da Saudade Formation are gently folded, with North-South axes and subvertical axial plane, but without evidence of metamorphic cleavage (Fig. 1). Columnar sections of the Serra da Saudade Formation in the two studied locations are shown in Figure 2.

Several distinct lithofacies can be differentiated based on granulometry, sedimentary structures, bed geometry and mineralogy (Tab. 1). According to its composition, the lithofacies of the Serra da Saudade Formation can be divided into siliciclastic (Figs. 3 and 4), phosphatic, carbonatic and volcaniclastic facies (Fig. 5). Siliciclastic facies are composed of green to yellowish sandstone, gray to beige siltstone, mud-silt-sand rhythmite, green siltstone and glauconitic siltstone. Rocks mainly composed of phosphate intraclasts in a microcrystalline grained matrix rich in fluorapatite and colophane are named phosphatic rhythmites (Lima et al. 2007). Carbonate-rich rocks can be divided into dark-gray and fine-grained grainstones, intraformational breccias (rudstone) and dark-gray microbial laminites. The volcaniclastic facies identified by Moreira et al. (2020) can be further divided into a clay rich and a vesicular volcaniclastic rock.

\section{Green to yellowish sandstone}

The green to yellowish sandstone is predominant in the east, in the Cedro do Abaeté region. As described by Lima et al. (2007), it forms green to yellowish (when weathered) $5 \mathrm{~cm}$

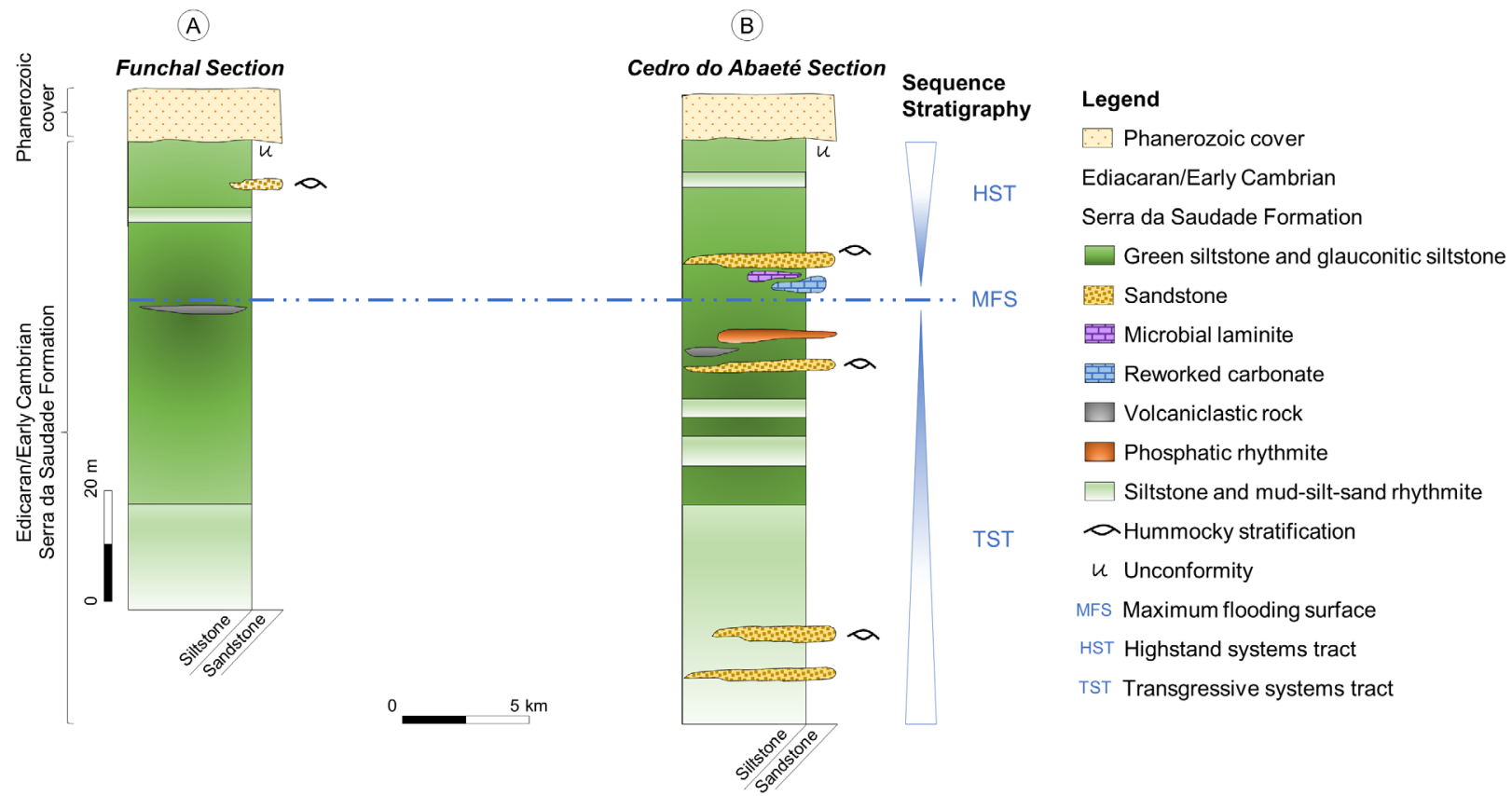

Source: modified from Moreira et al. (2020) and Lima et al. (2007), respectively.

Figure 2. Simplified columnar sections for the Serra da Saudade Formation, showing the lateral correlation of (A) Funchal and (B) Cedro do Abaeté sections, with facies and systems tract interpretation. 
Table 1. Summary of the lithofacies of the Serra da Saudade Formation: description and interpreted process and depositional environment.

\begin{tabular}{|c|c|c|c|}
\hline Type & Lithofacies & Description & $\begin{array}{c}\text { Interpretated Depositional } \\
\text { Environment }\end{array}$ \\
\hline
\end{tabular}

Lithofacies predominant in the east, in the region of Cedro do Abaeté (Lima et al. 2007). Green to yellowish Green to (when weathered) beds of $5 \mathrm{~cm}$ to $2 \mathrm{~m}$-thick, with a fine yellowish to medium-grained sandy base and a silt-mud top. Planar, sandstone wavy, and truncated lamination. Locally, hummocky cross-stratification with low angle truncated surfaces and wavelengths between 1 to $2 \mathrm{~m}$.

Siltstone Gray to beige, massive or laminated, coarse- to fine-grained siltstone locally interbedded with calciferous siltstone.

Siliciclastic
facies

Laminated rhythmites with varying proportions of mud, silt, and fine sand grains. May be intercalated with beds of fine-grained sandstone. It typically weathers to a reddish brown due to the presence of iron oxides and hydroxides. Load casts and flame structures are common.

Massive or laminated, medium to coarse grained green siltstone, occurring locally with truncated laminations. It shows grains of glauconite, subangular to subrounded grains of quartz and K-feldspar, clay minerals, detritic micas, opaques, and iron hydroxides. When glauconite content is greater than $40 \%$, as predominant in the west, in the region of Matutina and Funchal, it is classified as glauconitic siltstone.

Green and glauconitic siltstones

\begin{tabular}{|c|c|c|c|}
\hline $\begin{array}{l}\text { Phosphatic } \\
\text { facies }\end{array}$ & $\begin{array}{l}\text { Phosphatic } \\
\text { rhythmite }\end{array}$ & $\begin{array}{l}\text { Phosphatic sand-silt-clay rhythmites showing dark gray or } \\
\text { brown laminae (with manganese oxides) interbedded with } \\
\text { light gray laminae. The light gray laminae are composed of } \\
\text { phosphate intraclasts in a microcrystalline grained matrix } \\
\text { rich in fluorapatite, colophane, quartz, feldspar, muscovite, } \\
\text { chlorite, and calcite (Lima et al. 2007). }\end{array}$ & $\begin{array}{l}\text { The genesis of the phosphorite likely } \\
\text { occurred due to marine transgression } \\
\text { and upwelling on the marine shelf. A } \\
\text { later regression reworked the primary } \\
\text { phosphorite by waves and storm } \\
\text { currents on the continental shelf (Lima } \\
\text { et al. 2007). }\end{array}$ \\
\hline \multirow{3}{*}{$\begin{array}{l}\text { Carbonate } \\
\text { facies }\end{array}$} & $\begin{array}{l}\text { Reworked } \\
\text { carbonate }\end{array}$ & $\begin{array}{l}\text { Dark gray and fine-grained grainstone and intraformational } \\
\text { breccia (rudstone), with angular to subangular intraclasts. }\end{array}$ & $\begin{array}{l}\text { Formed by the action of waves and } \\
\text { currents on a shallow continental shelf. }\end{array}$ \\
\hline & $\begin{array}{l}\text { Microbial } \\
\text { laminite }\end{array}$ & $\begin{array}{l}\text { Dark gray microbial laminite, occasionally phosphatic, } \\
\text { showing typical crenulated and irregular laminations. }\end{array}$ & $\begin{array}{l}\text { Biogenic carbonate formed by } \\
\text { cyanobacteria and other microbial } \\
\text { lineages in a shallow marine } \\
\text { environment. }\end{array}$ \\
\hline & $\begin{array}{l}\text { Black organic- } \\
\text { matter-rich } \\
\text { micritic } \\
\text { limestone } \\
\end{array}$ & $\begin{array}{l}\text { Black organic-matter-rich micritic limestone and light gray } \\
\text { ooid grainstone highly fractured. }\end{array}$ & $\begin{array}{l}\text { Related to high organic matter burial in } \\
\text { an inner to outer shelf environmental. }\end{array}$ \\
\hline $\begin{array}{l}\text { Volcaniclastic } \\
\text { facies }\end{array}$ & $\begin{array}{l}\text { Volcaniclastic } \\
\text { rocks }\end{array}$ & $\begin{array}{c}\text { Clay-rich, whitish to greenish, } 0.5 \mathrm{~m} \text {-thick layer composed } \\
\text { of angular quartz, muscovite, illite, kaolinite, euhedral and } \\
\text { rounded zircon grains and a few glauconite aggregates. } \\
\text { Whitish to greenish, very friable, containing vesicular } \\
\text { cavities and a porous matrix. }\end{array}$ & $\begin{array}{l}\text { Sedimentation of volcanic ashes and } \\
\text { resedimented volcanic material in } \\
\text { marine shelf. }\end{array}$ \\
\hline
\end{tabular}

to $2 \mathrm{~m}$-thick beds with a fine medium-grained sandy base and a silt-mud top (Figs. 3A and 3B). Planar, wavy, and truncated lamination as well as hummocky cross-stratification showing low-angle truncation surfaces and wavelengths between 1 to 2 meters are common. The sandstone is texturally and mineralogically immature. The grains are angular to subangular, ranging from silt to medium sand, composed of quartz, micas, chlorite, clay minerals, feldspar and minor minerals, such as zircon, rutile, and oxides. This lithofacies was deposited during the decreasing energy of storm waves on the continental shelf.

\section{Siltstone}

The base of the Serra da Saudade Formation, both in the São Gotardo and Cedro do Abaeté region, is marked by a
Deposited by the action of proximal storm waves on a marine shelf.

Fine-grained sediment deposited by weak traction currents or settling in a marine shelf environment.

Sand-silt-clayey sediment transported and deposited by weak or distal storm waves in marine environment.

Deposited by the action of distal storm waves on a marine shelf.

The genesis of the phosphorite likely occurred due to marine transgression and upwelling on the marine shelf. A ima et al. 2007)

Formed by the action of waves and

Biogenic carbonate formed by yanobacteria and other microbia environment.

Related to high organic matter burial in an inner to outer shelf environmental.

Sedimentation of volcanic ashes and marine shelf. typical gray siltstone (Fig. 3C). Its color is mainly dark gray, with some light brown or beige. The sedimentary structure is mainly horizontal lamination, with local occurrences of massive beds and a few intercalations of calciferous siltstone. In thin sections, neither cleavage nor metamorphic features were observed. The siltstone is composed of quartz, feldspar, and white mica. Quartz and K-feldspar grains are subrounded to subangular, smaller than $15 \mu \mathrm{m}$. The white mica is smaller than $15 \mu \mathrm{m}$, dispersed in the matrix and oriented according to the bedding. The opaque minerals are altered to orange hydroxides, likely goethite. Glauconite was not observed. These fine-grained sediments were deposited by weak traction currents or settled in a marine shelf environment. 



Figure 3. Siliciclastic lithofacies from the Serra da Saudade Formation: (A) verticalized yellowish sandstone with incipient hummocky crossstratification; (B) intercalation between green siltstone and green sandstone; (C) basal gray siltstone; (D) mud-silt-sand rhythmite (geologic hammer for scale is $28 \mathrm{~cm}$ long; the pen is $14.5 \mathrm{~cm}$ long).

\section{Mud-silt-sand rhythmite}

The gray siltstone grades upward into mud-silt-sand rhythmite (Fig. 3D). It is characterized by laminated rhythmite with varying proportions of mud, silt, and fine sand grains. It may be intercalated with fine-grained sandstone beds. The laminations are formed by interbedded green, fine-grained siltstones, and greenish gray to white, soft mudstone. When weathered, the clay laminae are typically a reddish brown due to the presence of iron oxides and hydroxides. Load casts and flame structures are common. The pale-green laminae have silt-sized grains and predominance of quartz, feldspar, and mica. Quartz and $\mathrm{K}$-feldspar grains are sub-rounded to sub-angular, smaller than $15 \mu \mathrm{m}$. The white mica is acicular, larger than $20 \mu \mathrm{m}$, dispersed in the matrix and oriented according to the bedding. The opaque minerals are altered to orange hydroxides, likely goethite. Glauconite is rare, subrounded and restricted to the green silty layers. A possible interpretation is that sandsilt-clayey sediments were transported and deposited by weak or distal storm waves in a marine environment.

\section{Green and glauconitic siltstones}

The green siltstone is the most common and abundant lithofacies in the study area and is widely distributed throughout the region (Fig. 4). The green siltstone is popularly denominated as "verdete" due to its typical olive or blueish-green color (Fig. 4A). It is a fine-grained siltstone, usually laminated, interbedded with massive levels and a few intercalations of darkgreen mudstone laminations. The mineral composition was described by several authors (e.g. Piza et al. 2011, Moreira et al. 2016) and is comprised of glauconite (up until 37\%), quartz (24\%), clay minerals (14\%), kaolinite (11\%), micas (7\%), opaque minerals and iron hydroxides (7\%). This lithofacies becomes thicker towards the east.

The green siltstone grades upward and laterally to the glauconitic siltstone. The glauconitic siltstone beds (Figs. 4B, 4C and 4D) are thicker and more homogeneous towards the west. It is a dark-green, fine-grained siltstone, with incipient lamination. Both the green and glauconitic siltstones are composed of subangular to subrounded grains of quartz and K-feldspar with surficial alteration, as well as acicular to lamellar detritic mica (muscovite, illite and minor biotite). Heavy minerals (manganese oxide, titanium oxide and zircon) are sub-rounded, with an average size of $5 \mu \mathrm{m}$. A clay fraction $\mathrm{X}$-ray diffractogram confirms the occurrence of glauconite (Fig. 4E). Few zircons, goethite, barium phosphate and rare-earth elements-rich phosphate minerals were also identified (Moreira et al. 2016).

According to a bibliographic review and descriptions in previous papers (Piza et al. 2011, Nader and Ackroyd 2017, Moreira et al. 2016, 2020), the main differences between the two units are the glauconitic content and its form. The green siltstone has few grains of $25 \mu \mathrm{m}$, with yellow to dark pleochroism, rounded and dispersed in the matrix. On the other hand, the glauconitic siltstone is composed of 40 to $80 \%$ of dark green micaceous glauconite (Fig. 4E), which is responsible for a whole-rock $\mathrm{K}_{2} \mathrm{O}$ content of approximately $10 \mathrm{wt} \%$ (Nader and Ackroyd 2017, Moreira et al.2016,2020). Although innumerous 

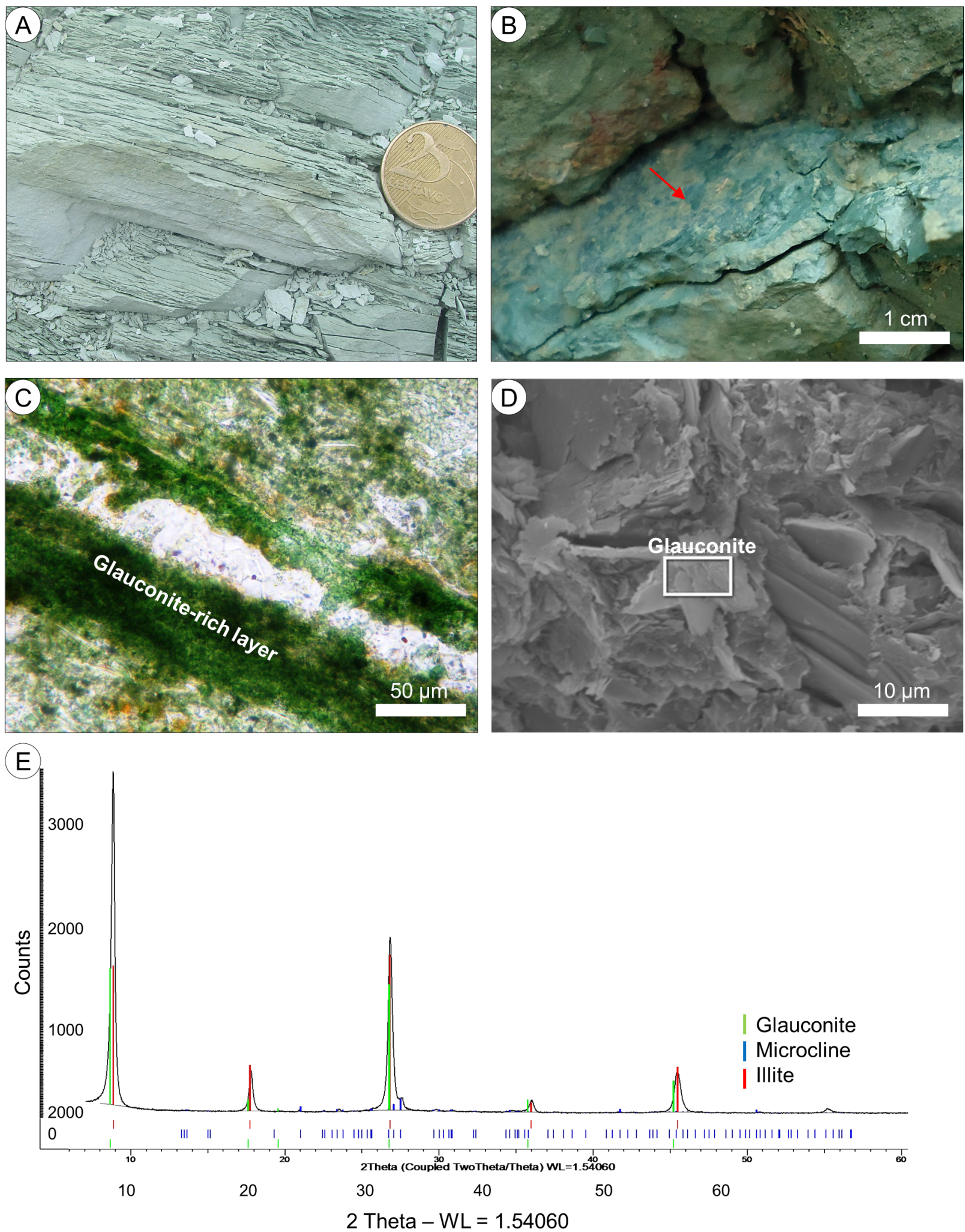

Figure 4. Main lithofacies of the Serra da Saudade Formation — green and glauconitic siltstones: (A) green siltstone (the coin for scale is $25 \mathrm{~mm}$ in diameter); (B) detail of glauconite-rich layer on glauconitic siltstone; (C) thin-section, parallel nichols, of glauconitic siltstone showing a glauconite-rich layer and glauconite grains on the matrix (green); (D) secondary electron image of a glauconite-rich layer; (E) clay fraction X-ray diffractogram of glauconitic siltstone.

studies regard the evaluation of the green siltstone ("verdete") as potassium source for agriculture (Piza et al.2011), up until recently, only the glauconitic siltstone was confirmed to be a fertilizer (Violatti et al. 2019). Both the green and the glauconitic siltstones were deposited by settling in an outer shelf context, in the absence of energy.

\section{Phosphatic rhythmite}

The phosphatic rhythmite is exclusively found in to the Cedro do Abaeté region (Figs. 2 and 5A) and was described by several authors (Guimarães 1967, Chaves et al. 1971, Lima 2005, Lima et al. 2007). Its thicknesses ranges from 0.5 to 2 meters (Lima 2005), and the beds are discontinuous and 



Figure 5. Subordinated lithofacies from the Serra da Saudade Formation: (A) phosphatic rhythmite - 7887395/427835 (in yellow the reaction of phosphorite with ammonium molybdate and nitric acid $100 \%$ solution; the coin for scale is $20 \mathrm{~mm}$ in diameter); (B) black organicmatter-rich micritic limestone - 388983/7832616 (the pencil is $20 \mathrm{~mm}$ long); (C) volcaniclastic rock — drill core - 405960/7872465 (the coin for scale is $18 \mathrm{~mm}$ in diameter); (D) volcaniclastic rock — outcrop - 420284/7869670 (the coin for scale is 20 mm in diameter).

lenticular in shape, having a general N-S direction. The layers are gently folded, but carry no clear evidence of schistosity or cleavage. The lithofacies is affected by different types of fractures and displays variable degrees of weathering. The P-rich rock is a sandy-pelitic rhythmite (phosphoarenite), interbedded with the green siltstone. Phosphatic sand-silt-clay rhythmite shows thin dark layers with manganese oxides interbedded with light gray laminae. The light gray intercalations are composed of phosphate intraclasts in a microcrystalline grained matrix, rich in fluorapatite, colophane, quartz, feldspar, muscovite, chlorite, and calcite (Lima et al. 2007). The genesis of the phosphorite likely occurred due to marine transgression and upwelling on the marine shelf. A later regression reworked the primary phosphorite by waves and storm currents on the continental shelf (Lima et al. 2007).

\section{Reworked Carbonate}

In the Cedro do Abaeté region, a reworked carbonate (Fig. 2) is locally interbedded to the green siltstone in a transitional contact (Lima et al.2007). It forms 2 to $3 \mathrm{~m}$-thick discontinuous lenses of dark, fine-grained grainstone, mudstone and intraformational breccia (rudstone). Sin-depositional (graded bed, cross-bedding and ripple marks) and post-depositional structures are common (slumps, mud cracks and dish structures), as well as millimetric to centimetric calcite veins. The lithofacies was formed by the action of waves and currents on a shallow continental shelf.

\section{Microbial Laminite}

In the Cedro do Abaeté region, Lima et al. (2007) described 2 to $3 \mathrm{~m}$-thick discontinuous lenses of a dark, fine-grained microbial laminite, which may exhibit phosphate contents interbedded to green siltstone and reworked carbonate. Crenulated and chaotic lamination structures are common, as well as millimetric to centimetric calcite veins. Biogenic carbonates were formed by cyanobacteria and other microbial lineages in a shallow marine environment.

\section{Black organic-matter-rich micritic limestone}

Close to the town of Santa Rosa da Serra (Figs. 2 and 5B), a 45 meter-thick, black organic-matter-rich micritic limestone and light gray oolitic grainstone were described and sampled. It comprises a decameter-thick lens of carbonate rock interbedded with siltstone and sandstone at the uppermost Serra da Saudade Formation. The black limestone is highly fractured, ranging from a mudstone to wackstone with peloids and oncoids, and grains of silt-sized quartz. Microbial laminite beds with disruptive and irregular micritic lamination occur sparsely in the middle and upper carbonate interval (Seer and Moraes 2011b). Preservation of the organic matter in the black, organic-matter-rich limestone likely resulted from the development of anoxic or at least oxygen-depleted bottom waters (Tucker 1983). This limestone is related to a high organic matter burial in an inner to outer shelf environment. 


\section{Volcaniclastic rock}

Volcaniclastic layers have been described by Moreira et al. (2020) as interbedded with both the glauconitic (to the west) and the green (to the east) siltstones. In the São Gotardo region, a fine-grained, whiteish to greenish, clay-rich layer ranging from 0.5 to $1.0 \mathrm{~m}$-thick, is interbedded with glauconitic siltstone (405960/7872465 - Fig. 5C). It is composed of angular quartz, muscovite, illite, kaolinite, zircon and a few glauconite aggregates. Similarly, near the village of Quartel de São João (South of Cedro do Abaeté — 420285/7869670 - Fig. 5D), a whitish to greenish, very friable bed outcrops. It has a very fine and porous matrix with a pale green to white color. These rocks are interpreted as sedimentation of volcanic ashes and resedimented volcanic material in the marine shelf.

\section{Stratigraphy and depositional architecture of the Serra da Saudade Formation}

The sedimentologic, stratigraphic and petrographic evaluation, combined with literature data, indicates that the Serra da Saudade Formation comprises a lateral and vertical assemblage that includes siliciclastic, volcaniclastic, phosphatic and carbonate facies. Green and glauconitic siltstones are the main lithofacies in the study area, while rhythmite, sandstone and reworked carbonate have a limited singular form in the east. Similarly, biogenic carbonate is restricted to the SW area.

The lithofacies are unevenly distributed both vertically and laterally (Fig. 6). In the lower Serra da Saudade Formation, gray to beige siltstone is commonly interbedded to mudstone and sandstone. The middle interval is composed of green and glauconitic siltstones, typically olive to blueish green. The upper lithofacies is comprised of weathered yellowish-brown siltstone with thin layers of sand-silt rhythmite, medium-grained felspathic sandstone and arkose. Interbedded with the upper siltstone outcrops a lenticular, black organic-matter-rich micritic limestone. From the southwest (São Gotardo area) to the northeast (Cedro do Abaeté area), a likely deep shelf environment with thick beds of glauconitic siltstone evolves into a storm-dominated, shallower marine system. The latter has a variable set of lithofacies, including green siltstone intercalated with sandstone and hummocky cross-stratification, reworked phosphorite and shallow water carbonate.

Regarding a sequence stratigraphic framework, the basal gray siltstone and part of green and glauconitic siltstone of the Serra da Saudade Formation represents a TST (Fig. 2). Sequences dominated by glauconite reflect the deposition on muddy bottoms, with a generally low oxygen content and intermittent action of bottom currents (Amorosi 1995, 1997, Amorosi et al. 2007). A maximum flooding surface (MFS Fig. 2) was inferred to be present in the interval with the highest $\mathrm{K}_{2} \mathrm{O}$ content $(\sim 11 \mathrm{wt} \%)$, within the glauconitic siltstone unit. The upper part of the formation includes green siltstone, reworked limestone, and an upward increasing number of sandstone beds also expanding in thickness, interpreted as a highstand system tract (HST). The phosphatic rhythmite is found interbedded with the green siltstones and is restricted to the Cedro do Abaeté area.

The phosphogenic events are traditionally associated with phosphorous-rich upwelling currents (Glenn et al. 1994). The occurrence of phosphorite deposits during the Cambrian is commonly related to an increase in both $\mathrm{Ca}$ and $\mathrm{P}$ in shallow ocean waters. In the early Cambrian, the elevated oxygen levels and high weathering rates are the likely cause behind the breakdown of terrigenous material, enhancing the nutrient supply to shallow ocean waters, which in return promotes increased primary production (Berner 2004, Brennan et al. 2004, Stammeier et al. 2019). The Serra da Saudade Formation's phosphatic deposits are likely associated with two events. They mark the establishment of high biological productivity and favorable redox conditions, promoting phosphorous trapping in the sediments. High primary productivity is not always a prerequisite for phosphorites, once phosphorous enrichment can be done through the redox cycling of iron and manganese, and thus $\mathrm{Fe}-\mathrm{P}$ or Mn-P co-precipitation (e.g. Jarvis et al. 1994, Wang and Van Cappellen 1996). The joint occurrence of phosphatic rhythmite and manganese-rich layers suggests a genetic link between Mn redox cycling and phosphorites in the Serra da Saudade Formation. The absence of phosphatic facies in the

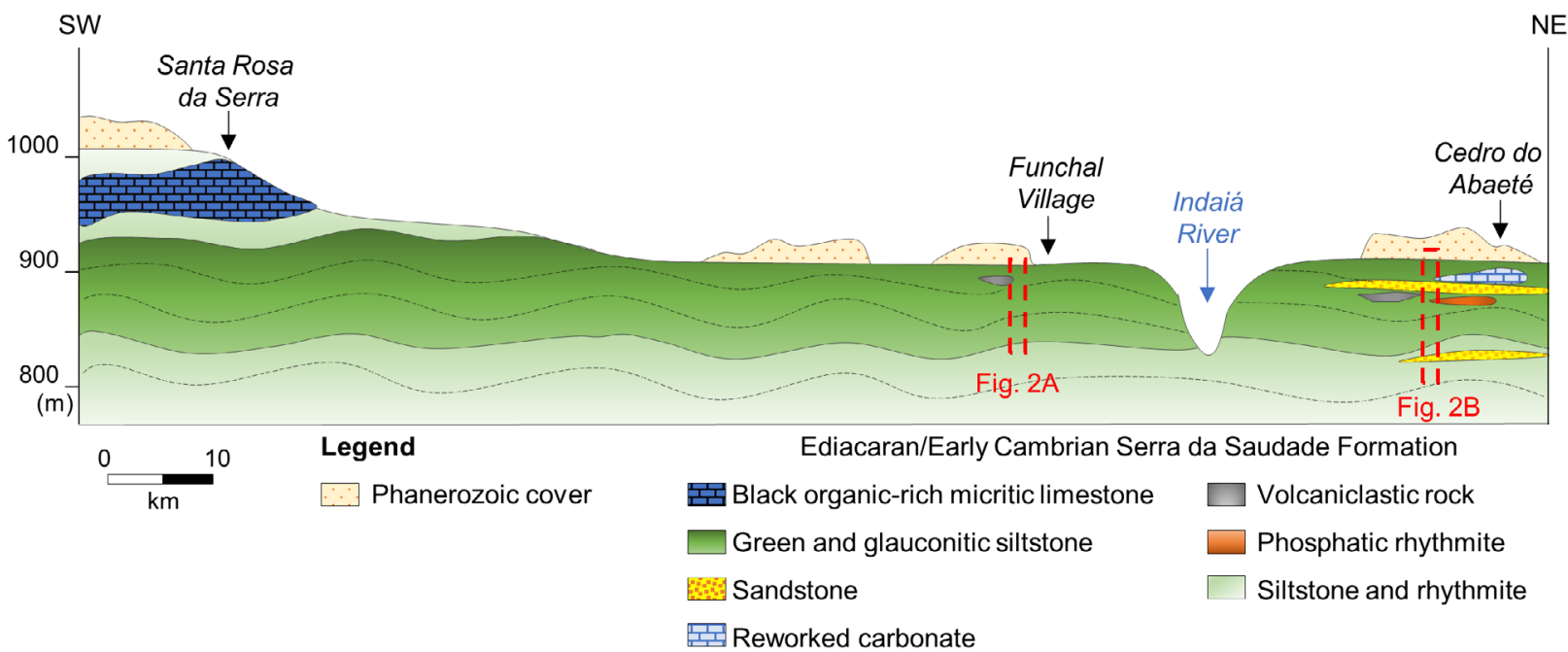

Figure 6. Schematic geological section for the Serra da Saudade Formation along the homonymous ridge (see location on Figure 1). Dotted red rectangles represent the columns detailed in Figure 2. 
western portion (São Gotardo area) may be attributed to an insufficient organic matter flux to the bottom sediments or inadequate redox conditions that favors $\mathrm{P}$ trapping. The second event regarding the formation of the phosphatic rhythmites is related to significant reworking by storm waves that concentrated coarser clasts and phosphorite grains in the eastern part of the basin, where it is related to expressive sandy sedimentation and reworked carbonates (following examples from Combes and Rey 2010, Crosby and Bailey 2012, Omelon et al. 2013, Stammeier et al.2019).

\section{Lithogeochemistry and Rare Earth Elements as paleoenvironmental proxies}

Four samples of black organic-matter-rich micritic limestone were analyzed for major and trace elements (Tab. 2). The carbonate samples show $\mathrm{Al}_{2} \mathrm{O}_{3}$ and $\mathrm{SiO}_{2}$ concentrations ranging from 0.14 to $4.51 \%$ and 2.15 to $21.84 \%$, respectively. $\mathrm{Zr}$ concentrations range from 17 to $67 \mathrm{ppm}$ and Sr abundances are higher than 2,000 ppm. The sum of rare earth elements plus yttrium ranges from 11.14 to $104.42 \mathrm{ppm}$. $\mathrm{Rb} / \mathrm{Sr}$ ratios range between 0.001 and $0.022, \mathrm{Mn} / \mathrm{Sr}$ from 0.04 to $0.10, \mathrm{Mg} / \mathrm{Ca}$ from 0.01 to 0.03 , and $\mathrm{Ca} / \mathrm{Sr}$ around 0.15 .

When normalized to PAAS data (McLennan, 1989), three samples (SR-02, SR-06, SR-07) present light rare earth elements (LREE) depletion relative related to heavy rare earth elements (HREE) $\left(\mathrm{Pr} / \mathrm{Yb}_{\mathrm{N}}=0.61\right.$ to 0.91$)$, and meanwhile the sample SR-12 sample is the only one showing LREE enrichment $(\mathrm{Pr} /$ $\mathrm{Yb}_{\mathrm{N}}=1.21$; Fig. 7). The three samples with $\operatorname{Pr} / \mathrm{Yb}_{\mathrm{N}}<1.0$ have show a positive $\mathrm{Ce}$ anomaly $\left(\mathrm{Ce} / \mathrm{Ce}^{*}=1.33\right.$ to 1.70$)$ and $\mathrm{Y} /$ Ho ratios from 40 to 44 . In contrast, the sample SR-12 shows absence oflacks the $\mathrm{Ce}$ anomaly and $\mathrm{Y} / \mathrm{Ho}=26$. All samples yield a positive $\mathrm{La}$ anomaly $\left(\mathrm{La} / \mathrm{La}^{*}=1.33\right.$ to 4.61$)$ and $\mathrm{Eu} /$ $\mathrm{Eu}^{*}$ around 1.0.

Sample SR-12 shows clear evidence suggesting contamination by detritic material and diagenetic overprint, such as LREE/HREE ${ }^{3}$ 1, low Y/Ho ratio and high contents of $\mathrm{Al}_{2} \mathrm{O}_{3}$, $\mathrm{SiO}_{2}, \mathrm{Zr}$ and $\mathrm{Rb}$ (Tab. 2 and Fig. 4). In contrast, the LREE depletion, high $\mathrm{Y} / \mathrm{Ho}$ ratios, low SREE and low $\mathrm{Al}_{2} \mathrm{O}_{3}, \mathrm{SiO}_{2}$, $\mathrm{Zr}$ and $\mathrm{Rb}$ contents of samples SR-02, SR-06 and SR-07 are characteristics of reasonably pure carbonates. Therefore, only these three last samples will be used in the following discussion concerning paleoenvironmental aspects.

The normalized REE $+Y$ data from the studied samples show similarities with modern oxic seawater (Alibo and Nozaki 1999) when comparing both $\mathrm{La}$ and Eu anomalies and $\mathrm{Pr} / \mathrm{Yb}_{\mathrm{N}}$ and $\mathrm{Y} /$ Ho ratios. However, instead of a negative Ce anomaly, typical of oxic waters, the data yield significant positive Ce anomalies. Positive $\mathrm{Ce}$ anomalies are usually interpreted as a fingerprint of an active Ce cycle, i.e. $\mathrm{Mn}^{2+}$ oxidation and sequestration of dissolved $\mathrm{Ce}^{4+}$ by $\mathrm{MnO}_{2}$ particles. Therefore, in oxic environments, hydrogenetic ferromanganese crusts are $\mathrm{Ce}$-enriched and usually present significant positive $\mathrm{Ce}$ anomalies (Bau and Koschinsky 2009), while carbonates deposited in the same redox environment are Ce-depleted and yield negative Ce anomalies (e.g. Tostevin et al. 2016). On the other hand, carbonates with a positive Ce anomaly, similarly to the studied samples, do not necessarily indicate significant changes in the redox conditions of the ocean. They may simply reflect subtle variations in the redox conditions of the underlying sediments during diagenesis (German and Elderfield 1990, Ling et al. 2013). Distinctive positive Ce anomalies, in some cases, reflect post-depositional Ce mobilization during the anoxic early diagenesis through reduction of $\mathrm{MnO}_{2}$ particles underneath the $\mathrm{Mn}$ (IV/II) redoxcline. Positive Ce anomalies may also be general features of alkaline, carbonate-rich and aerobic waters, although other typical rare earth elements behaviors in such environments are not found in these samples (Möller and Bau 1993). Carbonates with the positive Ce anomaly may also result from partial dissolution of Mn oxides contaminants during laboratory procedures; however, these samples are very lean in manganese $\left(\mathrm{MnO}_{2}<0.01 \mathrm{wt} \%\right)$ and do not show increase in Ce concentration with increasing $\mathrm{Mn}$ content. Therefore, the positive Ce anomalies suggest bottom water anoxic conditions and/or diagenetic environments during deposition of the Santa Rosa da Serra limestones. Ocean stratification and $\mathrm{O}_{2}$-poor environments are also described in the upper Sete Lagoas, Serra de Santa Helena and Lagoa do Jacaré formations (Iyer et al. 1995, Misi et al. 2007, Vieira et al. 2007, Alvarenga et al. 2014, Paula-Santos et al. 2017, Paula-Santos et al. 2018). However, further data are necessary to fully elucidate this issue.

\section{Isotopic data}

\section{Carbon and oxygen isotopic variations}

The studied limestone displays $\delta^{13} \mathrm{C}$ values ranging from 9.26 and $9.79 \%$, and negative $\delta^{18} \mathrm{O}$ values between -10.24 and $-9.35 \%$. One sample, SR-02, in the lowermost part of the section, showed negative $\delta^{13} \mathrm{C}$ value $(-8.75 \%$ ) and negative $\delta^{18} \mathrm{O}$ value (-11.50\%o) (Tab. 3, Fig. $\left.8 \mathrm{~A}\right)$. Apart from the carbon isotope data of sample SR-02, $\delta^{13} \mathrm{C}$ and $\delta^{18} \mathrm{O}$ values are relatively uniform throughout the sampled interval and there is no clear covariation between $\delta^{13} \mathrm{C}$ and $\delta^{18} \mathrm{O}$ when plotted in a binary diagram (Fig. 8B).

In the Bambuí Group, positive $\delta^{13} \mathrm{C}$ is related to shallow water carbonates, although the cause for the high $\delta^{13} \mathrm{C}$ values is still enigmatic (Iyer et al. 1995, Uhlein et al. 2019, CaetanoFilho et al. 2020, Cui et al. 2020). Positive $\delta^{13} \mathrm{C}$ values are described in the upper Sete Lagoas Formation (Santos et al. 2004, Vieira 2007) and Lagoa do Jacaré Formation (Misi et al. 2007) and are used as stratigraphic markers for the Bambuí Group (Paula-Santos et al. 2017, Uhlein et al. 2019). In the Jaíba Member, uppermost Serra da Saudade Formation (North of Minas Gerais), microbialites and grainstones show $\delta^{13} \mathrm{C}$ ranging from +0.8 to $+3.4 \%$ and $\delta^{18} \mathrm{O}$ happen mainly around $-8 \%$, with lighter oxygen isotopes in the lower interval (Uhlein et al. 2019, 2021).

The positive $\delta^{13} \mathrm{C}$ isotopic trend can be explained by various processes, such as an increase in burial rates of organic matter (Knoll et al. 1986); methanogenesis associated with fermentation and direct reduction of $\mathrm{CO}_{2}$ (Whiticar et al. 1986); sulfate reduction accompanied by sulfide generation under anaerobic conditions (Claypool and Kaplan 1974, Pierre 1989); high photosynthetic bio-productivity; high evaporation rates (Frimmel 
Braz. J. Geol. (2021), 51(3): e20210029

Table 2. Complete whole rock geochemical analysis for the black organic-rich micritic limestone.

\begin{tabular}{|c|c|c|c|c|c|}
\hline Sample & & SR-02 & SR-06 & SR-07 & SR-12 \\
\hline Height (m) & Unit & 1003 & 1013 & 1014 & 1032 \\
\hline $\mathrm{SiO}_{2}$ & $\%$ & 4.69 & 4.07 & 2.15 & 21.84 \\
\hline $\mathrm{Al}_{2} \mathrm{O}_{3}$ & $\%$ & 0.14 & 0.42 & 0.14 & 4.51 \\
\hline $\mathrm{Fe}_{2} \mathrm{O}_{3}$ & $\%$ & 0.31 & 0.44 & 0.23 & 1.66 \\
\hline $\mathrm{CaO}$ & $\%$ & 50.07 & 51.9 & 53.4 & 36.24 \\
\hline $\mathrm{MgO}$ & $\%$ & 0.39 & 0.34 & 0.53 & 1.22 \\
\hline $\mathrm{MnO}$ & $\%$ & $<0.01$ & $<0.01$ & 0.01 & 0,03 \\
\hline $\mathrm{TiO}_{2}$ & $\%$ & $<0.01$ & 0.03 & 0.01 & 0.26 \\
\hline $\mathrm{P}_{2} \mathrm{O}_{5}$ & $\%$ & 0.20 & 0.38 & 0.17 & 0.23 \\
\hline $\mathrm{Na}_{2} \mathrm{O}$ & $\%$ & 0.02 & 0.04 & 0.04 & 0.08 \\
\hline $\mathrm{K}_{2} \mathrm{O}$ & $\%$ & 0.06 & 0.14 & 0.07 & 1.51 \\
\hline LOI \% & $\%$ & 41.66 & 41.37 & 42.63 & 30.24 \\
\hline $\mathrm{Ba}$ & ppm & 94.00 & 165.00 & 119.00 & 253.00 \\
\hline $\mathrm{Ca}$ & $\mathrm{ppm}$ & 35.78 & 37.09 & 38.16 & 25.90 \\
\hline Co & ppm & 0.60 & 1.30 & 0.50 & 5.20 \\
\hline Cs & ppm & 0.07 & 0.21 & 0.11 & 1.62 \\
\hline $\mathrm{Cu}$ & ppm & 28.00 & 35.00 & 45.00 & 31.00 \\
\hline $\mathrm{Ga}$ & ppm & 0.20 & 0.60 & 0.20 & 6.00 \\
\hline $\mathrm{Hf}$ & $\mathrm{ppm}$ & 0.19 & 0.45 & $<0.05$ & 1.85 \\
\hline $\mathrm{Nb}$ & ppm & 1.72 & 0.54 & 0.07 & 5.10 \\
\hline $\mathrm{Ni}$ & ppm & 11.00 & 11.00 & 7.00 & 20.00 \\
\hline $\mathrm{Rb}$ & ppm & $<0.2$ & 3.10 & $<0.2$ & 50.40 \\
\hline Sn & ppm & 1.30 & $<0.3$ & $<0.3$ & 0.70 \\
\hline $\mathrm{Sr}$ & ppm & $2,155.00$ & $3,357.00$ & $2,051.00$ & $2,340.00$ \\
\hline $\mathrm{Ta}$ & ppm & 0.06 & $<0.05$ & $<0.05$ & 0.23 \\
\hline Th & ppm & 0.60 & 0.30 & $<0.1$ & 3.60 \\
\hline $\mathrm{U}$ & ppm & 0.78 & 1.15 & 1.02 & 1.71 \\
\hline V & ppm & 5.00 & 27.00 & 5.00 & 57.00 \\
\hline W & ppm & $<0.1$ & $<0.1$ & $<0.1$ & 0.20 \\
\hline $\mathrm{Zn}$ & ppm & 22.00 & $<5$ & $<5$ & $<5$ \\
\hline $\mathrm{Zr}$ & ppm & 17.00 & 24.00 & $<10$ & 67.00 \\
\hline $\mathrm{La}$ & ppm & 3.8 & 11.6 & 2.1 & 23.9 \\
\hline $\mathrm{Ce}$ & ppm & 3.8 & 8 & 3.3 & 34.9 \\
\hline $\mathrm{Pr}$ & ppm & 0.4 & 0.77 & 0.29 & 4.23 \\
\hline $\mathrm{Nd}$ & ppm & 2 & 3.4 & 1.5 & 16.4 \\
\hline $\mathrm{Sm}$ & ppm & 0.4 & 0.8 & 0.2 & 3.3 \\
\hline $\mathrm{Eu}$ & ppm & 0.08 & 0.16 & 0.08 & 0.61 \\
\hline Gd & ppm & 0.58 & 1.09 & 0.3 & 2.84 \\
\hline $\mathrm{Tb}$ & ppm & 0.06 & 0.14 & $<0.05$ & 0.35 \\
\hline Dy & ppm & 0.58 & 1.12 & 0.36 & 2.33 \\
\hline $\mathrm{Y}$ & ppm & 4.4 & 7.63 & 2.64 & 12.37 \\
\hline Ho & ppm & 0.11 & 0.19 & 0.06 & 0.47 \\
\hline $\mathrm{Er}$ & ppm & 0.28 & 0.63 & 0.21 & 1.29 \\
\hline $\mathrm{Tm}$ & ppm & $<0.05$ & 0.06 & $<0.05$ & 0.17 \\
\hline $\mathrm{Yb}$ & ppm & 0.2 & 0.4 & 0.1 & 1.1 \\
\hline $\mathrm{Lu}$ & ppm & $<0.05$ & 0.06 & $<0.05$ & 0.16 \\
\hline $\mathrm{La} / \mathrm{La}^{*}$ & & 3.72 & 4.61 & 3.04 & 1.33 \\
\hline $\mathrm{Ce} / \mathrm{Ce}^{*}$ & & 1.37 & 1.33 & 1.70 & 0.92 \\
\hline $\mathrm{Eu} / \mathrm{Eu}^{*}$ & & 0.92 & 0.85 & 2.27 & 0.85 \\
\hline
\end{tabular}




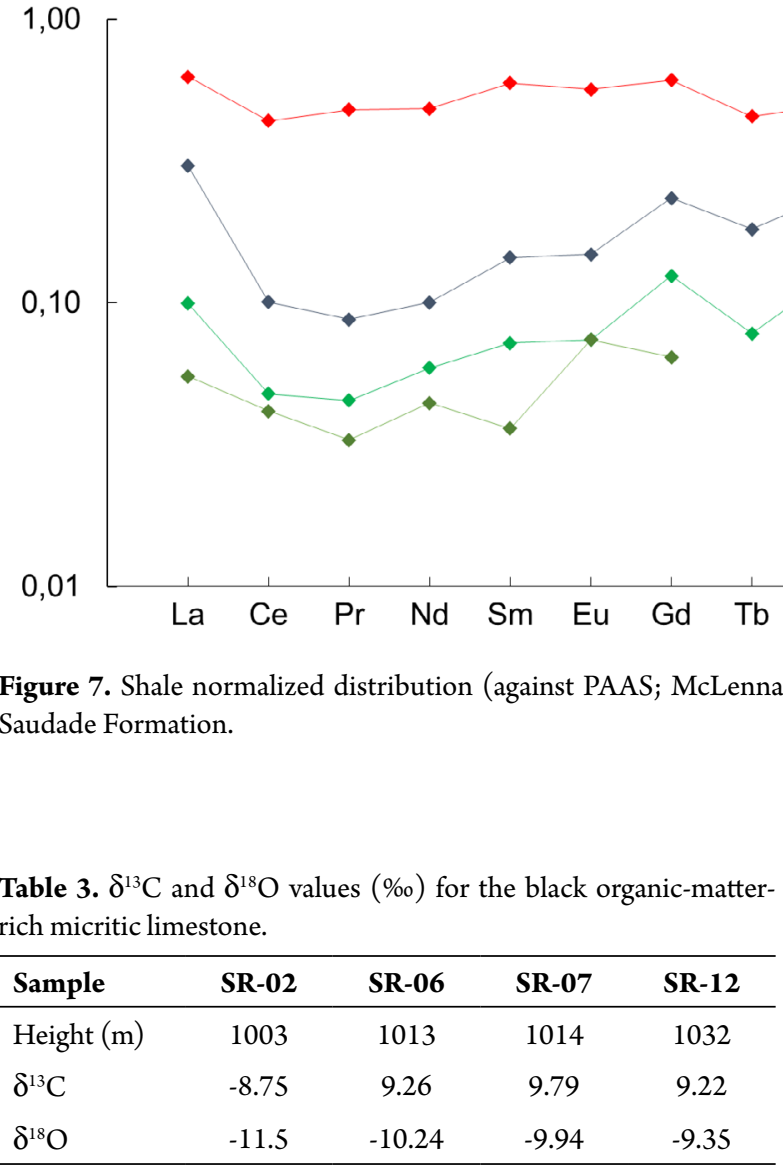

2010); as well as production and distribution of authigenic carbonate (Schrag et al. 2013, 2014). Additionally, carbon isotopes are subjected to seasonal variations due to their low residence time in the oceans, around 433 years (Frimmel 2010). It is likely that the very positive $\delta^{13} \mathrm{C}$ record in the upper Serra da Saudade Formation is the result of several processes that can be reflected in local or regional scales, similarly to those occurring in the Sete Lagoas and Lagoa do Jacaré formations (Guacaneme et al. 2017, Paula-Santos et al. 2017, Uhlein et al. 2019, Caetano-Filho et al. 2020, Cui et al. 2020).

\section{Sr isotopic variations}

Three samples analyzed for ${ }^{87} \mathrm{Sr} /{ }^{86} \mathrm{Sr}$ yielded low radiogenic ratios between 0.7074 to 0.7077 (Tab. 4). The Sr isotopic signature of the Bambuí Group is very characteristic. In the basal to middle Sete Lagoas Formation, the ${ }^{87} \mathrm{Sr} /{ }^{86} \mathrm{Sr}$ ratios range from 0.7074 to 0.7082 (Babinski et al. 2007). The chemostratigraphic interval that groups the upper Sete Lagoas, Serra de Santa Helena and Lagoa do Jacaré formations displays ${ }^{87} \mathrm{Sr} /{ }^{86} \mathrm{Sr}$ ratios around 0.7075 (Alvarenga et al. 2007, Misi et al. 2007, Caxito et al. 2012, Paula-Santos et al. 2015, Kuchenbecker et al. 2016, Guacaneme et al. 2017, PaulaSantos et al. 2017).

${ }^{87} \mathrm{Sr} /{ }^{86} \mathrm{Sr}$ ratios around 0.7075 are unexpected for late Ediacaran/lower Cambrian units when compared with published values worldwide (0.7080 to 0.7090; Li et al. 2013, Xiao et al. 2016). The occurrence of low ${ }^{87} \mathrm{Sr} /{ }^{86} \mathrm{Sr}$ in the Serra da Saudade Formation carbonates suggests that a similar basinal context, with a restricted depositional environment, either persisted or returned at the late stages of the Bambuí Basin. (Paula-Santos et al. 2017, Uhlein et al. 2019, Caetano-Filho et al. 2020, Cui et al. 2020). However, further data are necessary in order to delimit the duration and recurrence of the restricted basin setting.

\section{Depositional characteristics in a foreland basin}

The Serra da Saudade Formation was deposited in a foreland basin proximal to the Brasília Belt (e.g. Alkmim and MartinsNeto 2012, Reis et al. 2017, Uhlein et al. 2017), in which three depozones were defined, referred as foredeep, forebulge and back-bulge (Fig. 9). The initial deposition of the fine-grained sediments in the Serra da Saudade Formation occurred during periods of basin wide deepening and related to a TST (Fig. 9A). A thick interval of green siltstone suggests a period of sea level rise outpacing the sedimentary input and a maximum flooding surface positioned approximately at the richest glauconite interval, with higher $\mathrm{K}_{2} \mathrm{O}$ content. In the foredeep, the glauconitic siltstone interval is related to the maximum deepening of the basin. In the forebulge, to the east, a gently shallowing upward pattern is related to sandstones with hummocky cross-stratification and reworked limestone lenses (Fig. 9B). The black organic-rich limestone (Santa Rosa da Serra) suggests deposition in a beach barrier island-lagoonal succession at times of increased organic productivity and burial (Fig. 9C). It can be associated with long-term HST in the final stages of the Serra da Saudade Formation.

Marking the final stages of the Bambuí Group deposition (Fig. 9C), the Serra da Saudade Formation is covered by the Três Marias sandstone, also at Cambrian age (Tavares et al. 2020), which corresponds, in the central and western portion of the basin, to a storm deposit with paleocurrents toward the southeast and northeast (Chiavegatto 1992, Uhlein et al. 2004, Reis 2011). In the northwest portion of the basin (Jaíba area), deposition occurs in a coarsely grained deltaic system associated with a siliciclastic platform under 


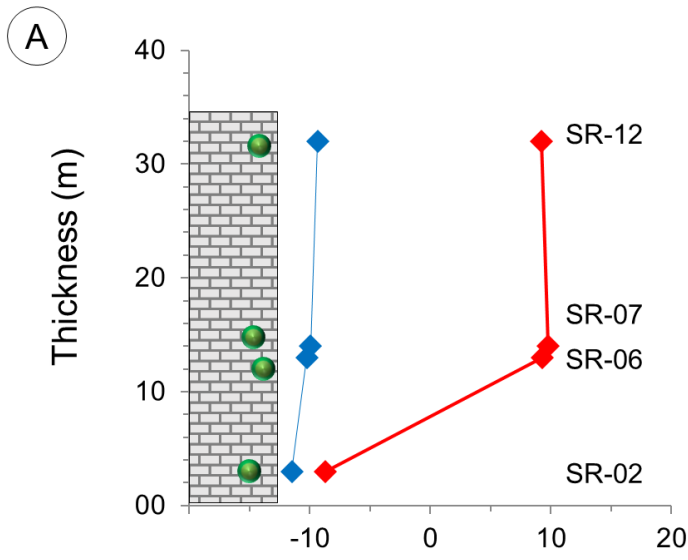

(B) $\delta^{13} \mathrm{C}_{\text {VPDB }} \%$

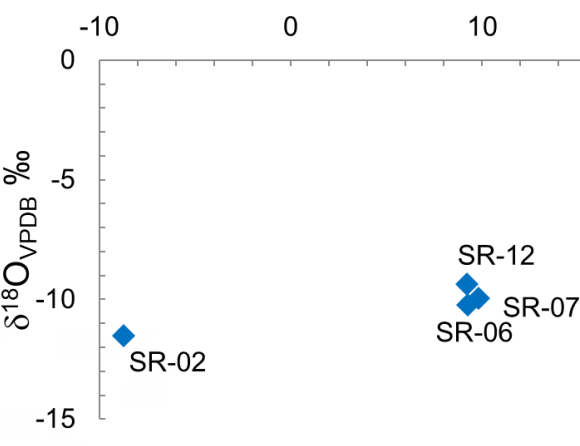

\section{Legend}

\section{Black organic-rich micritic limestone \\ - Sample \\ $\sim \delta^{18} \mathrm{O}_{\mathrm{VPDB}} \%$ \\ $\sim \delta^{13} \mathrm{C}_{\mathrm{VPDB}} \%$}

Figure 8. (A) Chemostratigraphic section for the black organic-matter-rich micritic limestone strata (upper Serra da Saudade Formation). (B) $\delta^{13} \mathrm{C}$ vs. $\delta^{18} \mathrm{O}$ diagram. The location of limestone quarry where the samples were collected is indicated on Figure 1.
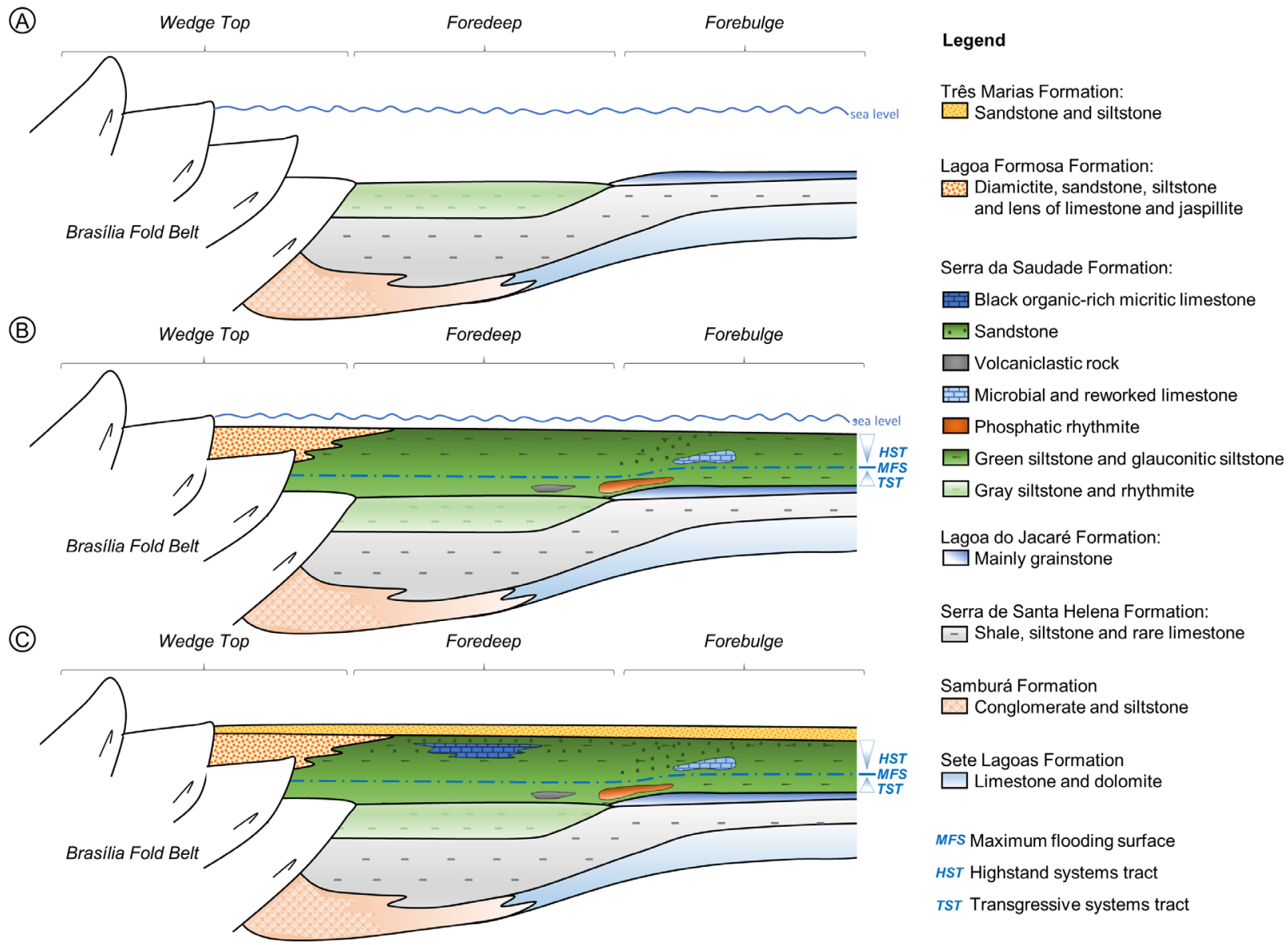

Figure 9. Schematic evolution model for the Serra da Saudade Formation (figure without scale — modified from Uhlein et al. 2017): (A) Beginning of deposition with basal siltstone and rhythmite in the foredeep. (B) The glauconitic siltstone marks the maximum flooding surface (MFS) in the foredeep; the forebulge, to the east, is marked by frequent intercalations of sandstone and carbonate. (C) Final stage of the Serra da Saudade Formation, with regressive carbonate deposition in the foredeep, which is overlain by fluvial to marine sandstone of the Três Marias Formation.

Table 4. Sr isotopic data for the black organic-rich micritic limestone.

\begin{tabular}{lccc}
\hline Sample & SR-02 & SR-06 & SR-12 \\
\hline Height (m) & 1003 & 1013 & 1032 \\
${ }^{87} \mathrm{Sr} /{ }^{86} \mathrm{Sr}$ & 0.7076 & 0.7074 & 0.7077 \\
$\mathrm{SE}(\%)$ & 0.0027 & 0.0030 & 0.0005 \\
\hline
\end{tabular}

the influence of waves, tides and storms with sediment dispersion to the southwest (Rossi et al. 2020). Both the upper Serra da Saudade and Três Marias formations represent the final stage of a shallowing upward second-order sequence (Dardenne 1981, Reis et al. 2017). 


\section{CONCLUSION}

The Serra da Saudade Formation comprises a laterally and vertically stacked assemblage dominated by pelitic packages containing siltstone with glauconite. Locally, rhythmite, sandstone with hummocky cross-stratification, phosphorite, volcaniclastic rocks, reworked carbonate and microbialite outcrop interbedded to siltstone. The lateral facies changes in the Serra da Saudade Formation reflect the transition from foredeep (west) to forebulge (east) deposits during the evolution of a foreland basin.

The lower Serra da Saudade Formation is dominated by gray siltstone with rare sandstone intercalations. Further up in the unit, a thick bed of green siltstone indicates a sea level rise, with a maximum flooding surface positioned at the glauconitic siltstone (and consequently, higher $\mathrm{K}_{2} \mathrm{O}$ content) interval. Above the previously mentioned portion, a progradational pattern is indicated by reworked carbonate, microbialite and storm-induced sandstone beds occurring more frequently within pale green and gray siltstone. From foredeep to forebulge (west to east), there are different vertical stacks of facies due to contrasting subsidence/uplift times and rates during the Bambuí foreland basin evolution. The occurrence of limestone in the upper Serra da Saudade Formation can be associated to a second-order sequence regression that culminates in the deposition of the Três Marias Formation's continental to shallow marine sandstone.

The normalized REE+Y data in the studied samples show similarities with modern oxic seawater. The data suggest anoxic conditions in bottom water/diagenetic paleoenvironments during deposition of the Santa Rosa da Serra limestone. The high $\delta^{13} \mathrm{C}$ values and low ${ }^{87} \mathrm{Sr} /{ }^{86} \mathrm{Sr}$ data in the Serra da Saudade
Formation corroborate to the hypothesis of a similar paleogeographic and biogeochemical scenario regarding the underlying units also bearing anomalous $\mathrm{C}$ and $\mathrm{Sr}$ isotopic data, such as the upper Sete Lagoas Formation and the Lagoa do Jacaré Formation. Since these data are usually indicative of a restricted basin setting for the Bambuí Basin, one should be aware that further data are necessary to better delimit the duration of such paleogeographic scenario and if it persisted in the entire basin evolution.

\section{ACKNOWLEDGEMENTS}

The authors are thankful for the financial support received from Fundação de Amparo à Pesquisa do Estado de Minas Gerais (FAPEMIG CRA — grant number APQ-01711-14) and from Conselho Nacional de Desenvolvimento Científico e Tecnológico (CNPq Universal n. 447449/2014-1). We also acknowledge Verde AgriTech PLC, Mineração Dornas Ltda, Centro de Microscopia e Microanálises, Instituto de Desenvolvimento e Pesquisa, Pontifícia Universidade Católica do Rio Grande do Sul — IDEIA-PUC-RS, Centro de Pesquisas Manoel Teixeira da Costa, Instituto de Geociências, Universidade Federal de Minas Gerais - CPMTC/IGC/ UFMG, Núcleo de Estudos Geoquímicos, Laboratório de Isótopos Estáveis, Departamento de Geologia, Universidade Federal de Pernambuco - NEG-LABISE, Laboratório de Geologia Isotópica, Instituto de Geociências, Universidade Federal do Rio Grande do Sul — IGC-UFRGS, and Programa de Pós Graduação em Geologia-IGC-UFMG.

\section{ARTICLE INFORMATION}

Manuscript ID: 2021029. Received on: 07/22/2020. Approved on: 06/08/2021

D.M. wrote the manuscript and prepared figures; A.U. wrote the first draft, improved the manuscript and figures through corrections and suggestions, took the photographs used on Figures 3A, 3C, 4A, 5A; G.U. revised and improved the manuscript, geological sections, took the photographs used on Figure 5D; A.S. provided $\mathrm{C}$ and $\mathrm{O}$ isotopic analysis, E.K. provided the ${ }^{87} \mathrm{Sr} /{ }^{86} \mathrm{Sr}$ isotopic analysis. Competing interests: The authors declare no competing interests.

\section{REFERENCES}

Algabri M., She Z., Jiao L., Papineau D., Wang, G., Zhang C., Tang D., Ouyang G., Zhang Y., Chen G., Li C. 2020. Apatite-glaucony association in the Ediacaran Doushantuo Formation, South China and implications for marine redox conditions. Precambrian Research, 347:105842. https://doi. org/10.1016/j.precamres.2020.105842

Alibo D.S., Nozaki Y. 1999. Rare earth elements in seawater: particle association, shale-normalization, and $\mathrm{Ce}$ oxidation. Geochimica et Cosmochimica Acta, 63(3-4):363-372. https://doi.org/10.1016/ S0016-7037(98)00279-8

Alkmim F.F., Martins-Neto M.A. 2001. A bacia intracratônica do São Francisco: arcabouço estrutural e cenários evolutivos. In: Pinto C.P., Martins-Neto M. (Eds.). A Bacia do São Francisco: geologia e recursos naturais. Belo Horizonte: SBG, p. 9-30.

Alkmim F.F., Martins-Neto M.A. 2012. Proterozoic first-order sedimentary sequences of the São Francisco craton, eastern Brazil. Marine and Petroleum Geology, 33(1):127-139. https://doi.org/10.1016/j. marpetgeo.2011.08.011
Alkmim F.F., Pedrosa-Soares A.C., Cruz S.C.P., Silva C.M.T. 2011. Mapview curves of the Brasiliano/PanAfrican Araçuaí and west Congolian belts: products of craton orogen interactions during the assembly of West Gondwana. In: Schmitt R.S., Trouw R., Carvalho I.S., Collins A. (Eds.), Gondwana Research, 14, Abstracts. Universidade Federal do Rio de Janeiro (UFRJ), Rio de Janeiro.

Alvarenga C.J.S., Giustina M.E.S.D., Silva N.G.C., Santos R.V., Gioia S.M.C.L., Guimarães E.M., Dardenne M.A., Sial A.N., Ferreira V.P. 2007. Variações dos isótopos de $\mathrm{C}$ e $\mathrm{Sr}$ em carbonatos pré e pós-glaciação Jequitaí (Esturtiano) na região de Bezerra-Formosa, Goiás - O Cráton São Francisco. Revista Brasileira de Geociências, 37(4 Supl.):147-155.

Alvarenga C.J.S., Santos R.V., Vieira L.C., Lima B.A.F., Mancini L.H. 2014. Meso-Neoproterozoic isotope stratigraphy on carbonates platforms in the Brasilia Belt of Brazil. Precambrian Research, 251:164-180. https://doi. org/10.1016/j.precamres.2014.06.011

AmorosiA. 1995. Glaucony and sequence stratigraphy: a conceptual framework of distribution in siliciclastic sequences. Journal of Sedimentary Research, 65 (4b):419425. https://doi.org/10.1306/D4268275-2B26-11D7-8648000102C1865D 
Amorosi A. 1997. Detecting compositional, spatial and temporal attributes of glaucony: a tool for provenance research. Sedimentary Geology, 109(12):135-153. https://doi.org/10.1016/S0037-0738(96)00042-5

Amorosi A., Sammartino I., Tateo F. 2007. Evolution patterns of glaucony maturity: A mineralogical and geochemical approach. Deep-Sea Research, 54(11-13):1364-1374. https://doi.org/10.1016/j.dsr2.2007.04.006

Babinski M., Pedrosa-Soares A.C., Trindade R.I.F., Martins M., Noce C.M., Liu D. 2012. Neoproterozoic glacial deposits from the Araçuaí orogen, Brazil: age, provenance and correlations with the São Francisco craton and West Congo belt. Gondwana Research, 21(2-3):451-465. https://doi. org/10.1016/j.gr.2011.04.008

Babinski M., Vieira L.C., Trindade R.I.F. 2007. Direct dating of the Sete Lagoas cap carbonate (Bambuí Group, Brazil) and implications for the Neoproterozoic glacial events. Terra Nova, 19(6):401-406. https://doi. org/10.1111/j.1365-3121.2007.00764.x

Banerjee S., Choudhury T.R., Saraswati P.K., Khanolkar S. 2020. The formation of authigenic deposits during Paleogene warm climatic intervals: a review. Journal of Palaeogeography, 9:27. https://doi.org/10.1186/ s42501-020-00076-8

Bau M., Koschinsky A. 2009. Oxidative scavenging of cerium on hydrous $\mathrm{Fe}$ oxide: evidence from the distribution of rare earth elements and yttrium between Fe oxides and $\mathrm{Mn}$ oxides in hydrogenetic ferromanganese crusts. Geochemical Journal, 43(1):37-47. https://doi.org/10.2343/ geochemj.1.0005

Berner R.A. 2004. The Phanerozoic carbon cycle: $\mathrm{CO}_{2}$ and $\mathrm{O}_{2}$. New York: Oxford University Press, $159 \mathrm{p}$.

Brennan S.T., Lowenstein T.K., Horita J. 2004. Seawater chemistry and the advent of biocalcification. Geology, 32(6):473-476. http://dx.doi. org/10.1130/G20251.1

Caetano-Filho S., Sansjofre P., Ader M., Paula-Santos G.M., Guacaneme C., Babinski M., Bedoya-Rueda C., Kuchenbecker M., Reis H.L.S., Trindade R.I.F. 2020. A large epeiric methanogenic Bambuí sea in the core of Gondwana supercontinent? Geoscience Frontiers, 12(1):203-218. http:// dx.doi.org/10.1016/j.gsf.2020.04.005

Castro P.T.A., Dardenne M.A. 2000. The sedimentology, stratigraphy and tectonic context of the São Francisco Supergroup at the southwestern domain of the São Francisco Craton, Brazil. Revista Brasileira de Geociências, 30(3):439-441.

Caxito F.A., Frei R., Uhlein G.J., Dias T.G., Árting T.B., Uhlein A. 2018. Multiproxy geochemical and isotope stratigraphy records of a Neoproterozoic oxygenation event in the Ediacaran Sete Lagoas cap carbonate, Bambuí Group, Brazil. Chemical Geology, 481:119-132. https:// doi.org/10.1016/j.chemgeo.2018.02.007

Caxito F.A., Halverson G.P., Uhlein A., Stevenson R., Dias T.G., Uhlein G.J. 2012. Marinoan glaciation in east central Brazil. Precambrian Research, 200203:38-58. http://dx.doi.org/10.1016/j.precamres.2012.01.005

Chaves A.G., Heineck A., Tavares W.D.P. 1971. Mapa Geológico: Folha de Vila Funchal. Escala 1: 50.000. Belo Horizonte: Projeto Fosfato Cedro do Abaeté.

Chiavegatto J.R.S. 1992. Análise estratigráfica das sequencias tempestíticas da Formação Três Marias (Proterozóico Superior), na porção meridional da Bacia do São Francisco. MS Dissertation, Universidade Federal de Ouro Preto, Ouro Preto, 216 p.

Chiavegatto J.R.S., Gomes N.S., Dardenne M.A., Delgado C.E.R. 2003. Estratigrafia do Grupo Bambuí nas regiões Norte de Minas Gerais: uma nova unidade estratigráfica e um contexto de inversão de bacia. In: Simpósio de Geologia de Minas Gerais, 12., Ouro Preto. Anais, v. 24.

ClaypoolG.E.,KaplanI.R. 1974. The Origin andDistribution ofMethanein Marine Sediments.In:KaplanI.R.(ed.).Natural GasesinMarineSediments. MarineScience, 3:99-139. Boston: Springer. https://doi.org/10.1007/978-1-4684-2757-8_8

Combes C., Rey C. 2010. Amorphous calcium phosphates: Synthesis, properties and uses in biomaterials. Acta Biomaterialia, 6(9):3362-3378. https://doi.org/10.1016/j.actbio.2010.02.017

Cook P.J., Shergold J.H. 1984. Phosphorus, phosphorites and skeletal evolution at the Precambrian-Cambrian boundary. Nature, 308:231-236. https://doi.org/10.1038/308231a0

Cordani U.G., Sato K., Teixeira W., Tassinari C.C.G., Basei M.A.S. 2000. Crustal evolution of the South American platform. In: Cordani U.G., Milani E.J., Thomaz Filho A., Campos D.A. (eds.). Tectonic evolution of South America. Rio de Janeiro: Brazilian Academy of Science, p. 19-40.
Costa D.A. 2011. Controle lito-estrutural e estratigráfico na hidrogeoquímica e nas concentrações de fluoreto no sistema aquífero cárstico-fissural do Grupo Bambuí, norte de Minas Gerais. MS Dissertation, Instituto de Geociências, Universidade Federal de Minas Gerais, Belo Horizonte.

Costa M.T., Branco 1961. Roteiro para a excursão Belo Horizonte Brasília. In: Congresso Brasileiro de Geologia, 14., Belo Horizonte. Anais... EEUFMG-Instituto de Pesquisas Radioativas, 25 p.

Crockford P.W., Hodgskiss M.S.W., Uhlein G.J., Caxito F.A., Hayles J.A., Halverson G.P. 2018. Linking paleocontinents through triple oxygen isotope anomalies. Geology, 46(2):179-182. https://doi.org/10.1130/G39470.1

Crosby C.H., Bailey J. 2012. The role of microbes in the formation of modern and ancient phosphatic mineral deposits. Frontiers in Microbiology, 3:241. https://dx.doi.org/10.3389\%2Ffmicb.2012.00241

Cui H. Warren L.V., Uhlein G.J., Okubo J., Lui X., Plummer R.E., Baele J., Goderis S., Claeys P., Li F. 2020. Global or regional? Constraining the origins of the middle Bambuí carbon cycle anomaly in Brazil. Precambrian Research, 348:105861. https://doi.org/10.1016/j.precamres.2020.105861

Dardenne M.A. 1978. Síntese sobre a estratigrafia do Grupo Bambuí no Brasil Central. In: Congresso Brasileiro de Geologia, 30., Recife. Anais... SBG, 2, p. 597-610.

Dardenne M.A. 1981. Os grupos Paranoá e Bambuí na Faixa Dobrada Brasília. In: Simpósio sobre o Cráton do São Francisco e suas Faixas Marginais. Anais... Salvador: CPRM, p. 140-147.

Dardenne M.A. 2000. The Brasilia Fold Belt. In: Cordani U.G., Milani A.J., Thomaz-Filho A., Campos D.A. Tectonic evolution of South America. In: International Geological Congress, 31., Rio de Janeiro. Anais... p. 231-264.

De Celles P.G., Giles K.A. 1996. Foreland basin systems. Basin Research, 8(2):105-123. https://doi.org/10.1046/j.1365-2117.1996.01491.

Dooley J. 2006. Glauconite. In: Kogel J., Trivedi N., Barrer J., Krukowski N. (Eds.). Industrial Minerals and Rocks: Commodities, Markets and Uses. Society for Mining, Metallurgy and Exploration, p. 495-506.

Flicoteaux R., Trompette R. 1998. Cratonic and foreland Early Cambrian phosphorites of West Africa: palaeoceanographical and climatical contexts. Palaeogeography, Palaeoclimatology, Palaeoecology, 139(3-4):107-120. https://doi.org/10.1016/S0031-0182(97)00141-7

Föllmi K.B. 1996. The phosphorus cycle, phosphogenesis and marine phosphate rich deposits. Earth-Science Reviews, 40(1-2):55-124. https:// doi.org/10.1016/0012-8252(95)00049-6

Frimmel H.E. 2010. On the reliability of stable carbon isotopes for Neoproterozoic chemostratigraphic correlation. Precambrian Research, 182(4):239-253. https://doi.org/10.1016/j.precamres.2010.01.003

German C.R., Elderfield H. 1990. Application of the Ce anomaly as a paleoredox indicator: The ground rules. Paleoceanography, 5(5):823-883. https://doi.org/10.1029/PA005i005p00823

Glenn C.R., Follmi K.B., Riggs S.R., Baturin G.N., Grimm K.A., Trappe J., Abed A.M., Galli-Olivier C., Garrison R.E., Ilyyin AV., Jhel C., Rohrlich V., Sadaqah R.M.Y., Schidlowski M., Sheldon R.E., Siegmund H. 1994. Phosphorus and Phosphorites: Sedimentology and Environments of Formation. Eclogae Geologicae Helvetiae, 87(3):747-788.

Guacaneme C., Babinski M., Paula-Santos G.M., Pedrosa-Soares A.C. 2017. $\mathrm{C}, \mathrm{O}$ and $\mathrm{Sr}$ isotopic variations in Neoproterozoic-Cambrian carbonate rocks from the Sete Lagoas Formation (Bambuí Group), in the southern São Francisco basin, Brazil. Brazilian Journal of Geology, 47(3):521-543. https://doi.org/10.1590/2317-4889201720160126

Guimarães D. 1967. Ocorrências de fosforita no município de Abaeté. Rio de Janeiro: DNPM-DGM, 18 p.

Guimarães D., Dutra C.V. 1969. Contribuição ao estudo da Série Bambuí. Boletim DNPM, (234).

Iglesias M., Uhlein A. 2009. Estratigrafia do Grupo Bambuí e coberturas fanerozóicas no vale do rio São Francisco, norte de Minas Gerais. Revista Brasileira de Geociências, 39(2):256-266.

Iyer S.S., Babinski M., Krouse H.R., Chemale Jr. F. 1995. Highly ${ }^{13}$ C-enriched carbonate and organic matter in the Neoproterozoic sediments of the Bambuí Group, Brasil. Precambrian Research, 73(1-4):271-282. https://doi. org/10.1016/0301-9268(94)00082-3

James N.P., Dalrymple R.W. 2010. Facies Models 4. St. John's, Geological Association of Canada, $586 \mathrm{p}$. 
Jarvis I., Burnett W.C., Nathan Y., Almbaydin F.S.M., Attia A.K.M., Castro L.N., Flicoteaux R., Hilmy M.E., Husain V., Qutawnnah A.A., Serjani A., Zanin Y.N. 1994. Phosphorite geochemistry: state of the art and environmental concerns. Eclogae Geologicae Helvetiae, 87(3):643-700.

Kelmer L.R. 2019. Análise estratigráfica e geocronológica da sucessão siliciclástica-carbonática da porção superior do Grupo Bambuí na Serra do Jaíba, norte de Minas Gerais. MS Dissertation, Universidade Federal de Ouro Preto, Ouro Preto, $100 \mathrm{p}$

Knoll A.H., Hayes J.M., Kaufman A.J., Swett K., Lambert I.B. 1986. Secular variation in carbon isotope ratios from upper Proterozoic successions of Svalbard and East Greenland. Nature, 321:832-837. https://doi. org/10.1038/321832a0

Kuchenbecker M., Babinski M., Pedrosa-Soares A.C., Lopes-Silva L., Pimenta F. 2016. Chemostratigraphy of the lower Bambuí group, southwestern São Francisco craton, Brazil: insights on Gondwana paleoenvironments. Brazilian Journal of Geology, 46(Suppl. 1):145-162. https://doi.org/10.1590/2317-488920160030285

Lawrence M.G., Greig A., Collerson K.D., Kamber B.S. 2006. Rare Earth Element and Yttrium Variability in South East Queensland Waterways. Aquatic Geochemistry, 12:39-72. https://doi.org/10.1007/ s10498-005-4471-8

Li D., Ling H.-F., Shields-Zhou G.A., Chen X., Cremonese L., Och L., Thirlwall M., Manning C.J. 2013. Carbon and strontium isotope evolution of seawater across the Ediacaran-Cambrian transition: evidence from the Xiaotan section, NE Yunnan, South China. Precambrian Research, 225:128147. https://doi.org/10.1016/j.precamres.2012.01.002

Lima O.N.B. 2005. Grupo Bambuí: Estratigrafia regional no Alto São Francisco e geologia dos depósitos fosfáticos da Serra da Saudade. MS Dissertation, Instituto de Geociências, Universidade Federal de Minas Gerais, Belo Horizonte, $142 \mathrm{p}$.

Lima O.N.B., Uhlein A., Britto W. 2007. Estratigrafia do Grupo Bambuí na Serra da Saudade e geologia do depósito fosfático de Cedro do Abaeté, Minas Gerais. Revista Brasileira de Geociências, 37(4 Suppl.):204-215.

Ling H., Chen X., Li D., Wang D., Shields-Zhou G.A., Zhou M. 2013. Cerium anomaly variations in Ediacaran-earliest Cambrian carbonates from the Yangtze Gorges area, South China: Implications for oxygenation of coeval shallow seawater. Precambrian Research, 225:110-127. https://doi. org/10.1016/j.precamres.2011.10.011

McLennan S.M. 1989. Rare earth elements in sedimentary rocks: Influence of provenance and sedimentary processes. Review in Mineralogy o Geochemistry, 21:169-200. https://doi.org/10.1515/9781501509032-010

Misi A., Kaufman A.J., Veizer J., Powis K., Azmy K., Boggiani P.C., Gaucher C., Teixeira J.B.G., Sanches A.L., Iyer S.S.S. 2007. Chemostratigraphic correlation of Neoproterozoic successions in South America. Chemical Geology, 237(1-2):143-167. https://doi.org/10.1016/j. chemgeo.2006.06.019

Möller P., Bau M. 1993. Rare-earth patterns with positive cerium anomaly in alkaline waters from Lake Van, Turkey. Earth and Planetary Science Letters, 117(3-4):671-676. https://doi.org/10.1016/0012-821X(93)90110-U

Moreira D.S., Uhlein A., Dussin I.A., Uhlein G.J., Misuzaki A.P. 2020. A Cambrian age for the upper Bambuí Group, Brazil, supported by the first $\mathrm{U}-\mathrm{Pb}$ dating of volcaniclastic bed. Journal of South American Earth Sciences, 99. https://doi.org/10.1016/j.jsames.2020.102503

Moreira D.S., Uhlein A., Fernandes M.L.S., Mizusaki A.M., Galéry R., Delbem I.D. 2016. Estratigrafia, petrografia, e mineralização de potássio em siltitos verdes do Grupo Bambuí na região de São Gotardo, Minas Gerais. Geociências, 35(2):157-171.

Nader B., Ackroyd B. 2017. NI 43-101 - Pre-Feasibility Technical Report Cerrado Verde Project, Minas Gerais, Brazil. London, Verde AgriTech PLC, $219 \mathrm{p}$.

Omelon S., Ariganello M., Bonucci E., Grynpas M., Nanci A. 2013. A review of phosphate mineral nucleation in biology and geobiology. Calcified Tissue International, 93(4):382-396. https://doi.org/10.1007/ s00223-013-9784-9

Özgüner A.M., Varol B. 2009. The genesis, mineralization, and stratigraphic significance of phosphatic/glauconitic condensed limestone unit in the Manavgat Basin, SW Turkey, Sedimentary Geology, 221 (1-4):40-56. https:// doi.org/10.1016/j.sedgeo.2009.07.011
Paula-Santos G.M., Babinski M., Kuchenbecker M., Caetano-Filho S., Trindade R.I.F., Pedrosa-Soares A.C. 2015. New evidence of an Ediacaran age for the Bambuí Group in southern São Francisco craton (eastern Brazil) from zircon $\mathrm{U}-\mathrm{Pb}$ data and isotope chemostratigraphy. Gondwana Research 28(2):702-720. https://doi.org/10.1016/j.gr.2014.07.012

Paula-Santos G.M., Caetano-Filho S., Babinski M., Trindade R.I., Enzweiler J. 2018. Rare earth elements of carbonate rocks from the Bambuí Group, southern São Francisco Basin, Brazil, and their significance as paleoenvironmental proxies. Precambrian Research, 305:327-340. https:// doi.org/10.1016/j.precamres.2017.12.023

Paula-Santos G.M., Caetano-Filho S., BabinskiM., Trindade R.I., Guacaneme C. 2017. Tracking connection and restriction of West Gondwana São Francisco basin through isotope chemostratigraphy. Gondwana Research, 42:280-305. https://doi.org/10.1016/j.gr.2016.10.012

Pierre C. 1989. Sedimentation and diagenesis in restricted marine basins. In: Fritz P., Fontes J.C.H. (Eds.). Handbook of Environmental Isotope Geochemistry. The Marine Environment. A. Amsterdam: Elsevier, v. 3, p. 257-315.

Pimentel M.M., Dardenne M.A., Fuck R.A., Viana M.G., Junges S.L., Fischel D.P., Seer H., Dantas E.L. 2001. Nd isotopes and the provenance of detrital sediments of the Neoproterozoic Brasilia Belt, Central Brazil. Journal of South American Earth Sciences, 14(6):571-585. https://doi.org/10.1016/ S0895-9811(01)00041-4

Piza P.D.D.T., Bertolino L.C., Silva A.A.S., Sampaio J.A., Luz A.B. 2011 Verdete da região de Cedro do Abaeté (MG) como fonte alternativa para potássio. Geociências, 30(3):345-356.

Proust J.N., Chuvashov B.I., Vennin E., Boisseau T. 1998. Carbonate platform drowning in a foreland setting; the Mid-Carboniferous platform in western Urals (Russia). Journal of Sedimentary Research, 68(6):1175-1188. https://doi.org/10.2110/jsr.68.1175

Pruss S.B., Jones D.S., Fike D.A., Tosca N.J., Wignall P.B. 2019. Marine anoxia and sedimentary mercury enrichments during the late Cambrian SPICE event in northern Scotland. Geology, 47(5):475-478. https://doi. org/10.1130/G45871.1

Reading H.G. (ed.). 1996. Sedimentary Environments: Processes, Facies and Stratigraphy. 3. ed. Oxford: Blackwell Scientific Publications, 557 p.

Reis H.L.S. 2011. Estratigrafia e tectônica da Bacia do São Francisco na zona de emanações de gás natural do baixo Rio Indaiá (MG). Thesis, Universidade Federal de Ouro Preto, Ouro Preto, 127 p.

Reis H.L.S., Suss J., Fonseca R.C.S., Alkmim F.F. 2017. Ediacaran forebulge grabens of the southern São Francisco Basin, SE Brazil: Craton interior dynamics during West Gondwana assembly. Precambrian Research, 302:150170. https://doi.org/10.1016/j.precamres.2017.09.023

Riggs S.R., Sheldon R.P. 1990. Phosphorite distribution: Upper Cenozoic. In: Burnett W.C., Riggs S.R. Phosphate Deposits of the World. Neogene to Modern Phosphorites. Cambridge: Cambridge University Press, v. 3, p. 205 222. (Cambridge Earth Science Series).

Rodrigues J.B. 2008. Proveniência de sedimentos dos grupos Canastra, Ibiá, Vazante e Bambuí-Um estudo de zircões detríticos e Idades Modelo Sm-Nd. $\mathrm{PhD}$ Thesis, Universidade de Brasília, Brasília, 128 p.

Rossi A.V.A., Danderfer Filho A., Bersan S.M., Kelmer L.R., Tavares T.D., Lana C. 2020. Stratigraphic, isotopic, and geochronological record of a superposed pro-foreland basin in the eastern São Francisco craton during west Gondwana amalgamation. Journal of South American Earth Sciences, 97:102406. https://doi.org/10.1016/j.jsames.2019.102406

Sanchez E.A.M., Uhlein A., Fairchild T.R. 2021. Treptichnus pedum in the Três Marias Formation, south-central Brazil, and its implications for the Ediacaran-Cambrian transition in South America. Journal of South American Earth Sciences, 105:102983. https://doi.org/10.1016/j. jsames.2020.102983

Santos R.V., Alvarenga C.J.S., Babinski M., Ramos M.L., Cukrov N., Fonseca M.A., Sial A.N., Dardenne M.A., Noce C.M. 2004. Carbon isotopes of Mesoproterozoic-Neoproterozoic sequences from Southern São Francisco craton and Araçuaí Belt, Brazil: Paleographic implications. Journal of South American Earth Sciences, 18(1):27-39. https://doi.org/10.1016/j. jsames.2004.08.009

Schrag D.P., Higgins J.A., Macdonald F.A., Johnston D.T. 2013. Authigenic carbonate and the history of the global carbon cycle. Science, 339 (6119):540543. https://doi.org/10.1126/science.1229578 
Schrag D.P., Higgins J.A., Macdonald F.A., Johnston D.T. 2014. Authigenic carbonate and the history of the global carbon cycle: Why diagenesis matters even more. Goldschmidt Abstracts, 2223.

Seer H.J., Moraes L.C. 2011a. Mapa geológico Folha Campos Altos. Belo Horizonte: CODEMIG-UFMG.

Seer H.J., Moraes L.C. 2011b. Projeto Alto Paranaíba. Folha Campos Altos. Belo Horizonte: CODEMIG-UFMG, 165 p.

Sial A.N., Dardenne M.A., Misi A., Pedreira A.J., Gaucher C., Ferreira V.P., Silva Filho M.A., Uhlein A., Pedrosa-Soares A.C., Santos R.V., Egydio-Silva M., Babinski M., Alvarenga C.J.S., Fairchild T.R., Pimentel M.M. 2009. The São Francisco Paleocontinent. In: Gaucher C., Sial A.N., Halverson G.P., Frimmel H.E. (Eds.). Neoproterozoic-Cambrian Tectonics, Global Change and Evolution: a focus on southwestern Gondwana. Developments in Precambrian Geology. Amsterdam Elsevier, 16, p. 31-69.

Signorelli N., Tuller M.P., Silva P.C.S., Justo L.J.E.C. 2003. Carta Geológica Folha SE.23-Y-D - Bom Despacho, escala 1:250.000. Belo Horizonte: Serviço Geológico do Brasil - CPRM.

Silva M.A., Pinto C.P. 2014. Mapa geológico do Estado de Minas Gerais. Escala 1:1.000.000. Belo Horizonte: Serviço Geológico do Brasil - CPRM.

Stammeier J.A., Hipples D., Nebel O., Leis A., Grengg C., Mittermayr F., Kasemann S.A., Dietzel M. 2019. Radiogenic Sr and Stable C and O Isotopes Across Precambrian-Cambrian Transition in Marine Carbonatic Phosphorites of Malyi Karatau (Kazakhstan) - Implications for Paleoenvironmental Change. Geochemistry, Geophysics, Geosystems, 20(1):3-23. https://doi.org/10.1029/2018GC007767

Tavares T.D., Martins M.S., Alkmim F.F., Lana C. 2020. Detrital zircons from the Upper Três Marias Formation, São Francisco basin, SE Brazil: Record of foreland deposition during the Cambrian? Journal of South American Earth Sciences, 97:102395. https://doi.org/10.1016/j.jsames.2019.102395

Tostevin R., Shields G.A., Tarbuck G.M., He T., Clarkson M.O., Wood R.A. 2016. Effective use of cerium anomalies as a redox proxy in carbonatedominated marine settings. Chemical Geology, 438:146-162. https://doi. org/10.1016/j.chemgeo.2016.06.027

Trompette R.R. 1994. Geology of Western Gondwana (2000-500 Ma). PanAfrican-Brasiliano aggregation of South America and Africa. Rotterdam: A.A. Balkema, $350 \mathrm{p}$.

Tucker M.E. 1983. Sedimentation of organic-rich limestones in the late Precambrian of Southern Norway. Precambrian Research, 22(3-4):295-315. https://doi.org/10.1016/0301-9268(83)90053-0

Udgata D.B.P. 2007. Glauconite as an indicator of sequence stratigraphic packages in a lower paleocene passive margin shelf sucession, Central Alabama. MS Dissertation, Graduate Faculty of Auburn University, Auburn, 124 p.

Uhlein A., Baptista M.C., Seer H.J., Caxito F.A., Uhlein G.J., Dardenne M.A. 2011. A Formação Lagoa Formosa, Grupo Bambuí (MG): sistema deposicional de leque submarino em bacia de antepaís. Geonomos, 19(2):163-172. https://doi.org/10.18285/geonomos.v19i2.51
Uhlein A., Lima O.N.B., Fantinel L.M., Baptista M.C. 2004. Estratigrafia e evolução geológica do Grupo Bambuí, Minas Gerais (Roteiro Geológico). In: Congresso Brasileiro de Geologia, 42., Araxá. Anais... p. 30-61.

Uhlein G.J., Caxito F.A., Frei R., Uhlein A., Sial A.N., Dantas E.L. 2021. Microbially induced chromium isotope fractionation and trace elements behavior in lower Cambrian microbialites from the Jaíba Member, Bambuí Basin, Brazil. Geobiology, 19(2):125-146. https://doi.org/10.1111/ gbi. 12426

Uhlein G.J., Uhlein A., Pereira E., Caxito F.A., Okubo J., Warren L.V., Sial A.N. 2019. Ediacaran paleoenvironmental changes recorded in the mixed carbonate-siliciclastic Bambuí Basin, Brazil. Palaeo, 517:39-51. https://doi. org/10.1016/j.palaeo.2018.12.022

Uhlein G.J., Uhlein A., Stevenson R., Halverson G.P., Caxito F.A., Cox G.M. 2017. Early to late Ediacaran conglomeratic wedges from a complete foreland basin cycle in the southwest São Francisco Craton, Bambuí Group, Brazil. Precambrian Research, 299:101-116. https://doi.org/10.1016/j. precamres.2017.07.020

Valeriano C.M., Machado N., Simonetti A., Valladares C.S., Seer H.J., Simões L.S.A. 2004. U-Pb geochronology of the southern Brasília belt (SEBrazil): sedimentary provenance, Neoproterozoic orogeny and assembly of West Gondwana. Precambrian Research, 130(1-4):27-55. http://dx.doi. org/10.1016/j.precamres.2003.10.014

Vieira L.C. 2007. A Formação Sete Lagoas (Grupo Bambuí) e as Variações Paleoambientais no Final do Proterozóico. PhD Thesis, Universidade de São Paulo, São Paulo, 145 p

Vieira L.C., Trindade R.I.F, Nogueira A.C.R., Ader M. 2007. Identification of a Sturtian cap carbonate in the Neoproterozoic Sete Lagoas carbonate platform, Bambuí Group, Brazil. Comptes Rendus Geoscience, 339(3-4):240258. https://doi.org/10.1016/j.crte.2007.02.003

Violatti I.C.A., Gualberto C.A.C., Silveira L.H., Santos G.A., Ferreira B.C., Machado P.M.M., Pereira H.S. 2019. Glauconitic siltstone as multi-nutrient fertilizer for Urochloa brizantha cv. Marandú. Australian Journal of Crop Science, 13(8):1280-1287. https://doi.org/10.21475/ajcs.19.13.08.p1609

Wang Y., Van Cappellen P. 1996. A multicomponent reactive transport model of early diagenesis: application to redox cycling in coastal marine sediments. Geochimica et Cosmochimica Acta, 60(16):2993-3014. https:// doi.org/10.1016/0016-7037(96)00140-8

Warren L.V., Quaglio F., Riccomini C., Simões M.G., Poiré D.G., Strikis N.M., Anelli L.E., Strikis P.C. 2014. The puzzle assembled: Ediacaran guide fossil Cloudina reveals an old proto-Gondwana seaway. Geology, 42(5):391394. https://doi.org/10.1130/G35304.1

Whiticar M.J., Faber E., Schoell M. 1986. Biogenic methane formation in marine and freshwater environments: $\mathrm{CO}_{2}$ reduction versus acetate fermentation - Isotope evidence. Geochimica et Cosmochimica Acta, 50(5):693-709. https://doi.org/10.1016/0016-7037(86)90346-7

Xiao S., Narbonne G.M., Zhou C., Laflamme M., Grazhdankin D.V., Moczydłowska-Vidal M., Cui H. 2016. Toward an Ediacaran time scale: problems, protocols, and prospects. Episodes, 39(4):540-555. https://doi. org/10.18814/epiiugs/2016/v39i4/103886 